\title{
THE BOOK OF THE BODY OF CHRIST: JEWISH-CHRISTIAN MYSTICISM OF LETTERS AND THE NAME OF GOD AS AN ORIGIN FOR THE CHRISTIAN SPIRITUAL EXEGESIS
}

\section{INTRODUCTION}

In his article "The Body of the Text: a Kabbalistic Theory of Embodyment"1 E. R. Wolfson has expressed his views on the opposition as well as points of contact between the Jewish kabbalistic and medieval Christian treatment of the hermeneutics of the incorporation of the Divine Word into the letters of the Holy Scripture. This scholar formulated in general words the main points of his argument in the following way: "Pitched in the heartland of Christian faith, one encounters the logocentric belief in the incarnation of the word in the flesh of the person of Jesus, whereas in the textual panorama of medieval kabbalah, the site of the incarnational insight is the ontographic inscripting of flesh into word and the consequent conversion of the carnal body into the ethereal, luminous body, finally transposed into the literal body that is the letter, hyperliterally, the name that is the Torah. Both narratives, therefore, presume a correlation of body and book, but in an inverse manner: for Christians, the body is the embodyment of the book; for Jews, the book is the textualization of the body." 2

However, one should note a scholarly consensus concerning the parallelism of the Incarnation of Logos in the Person of Christ and the letters of the Scripture in such great Christian theorists of the biblical exegesis as Origen and Augustine. As this idea is expressed by D. Boyarin, "There is a virtual doubled Incarnation, then, in Origen's

(1) E. R. Wolfson, "The Body of the Text: a Kabbalistic Theory of Embodyment," The Jewish Quarterly Review, 95 (2005), pp. 479-500.

(2) Ibid., pp. 481-482. 
thinking. The Logos is incarnate in Jesus Christ and in Scripture as well." ${ }^{3}$ According to K. Froehlich, in Augustine "Bible and incarnation belong together," 4 and A. S. Miller wrote that "The Word was made flesh in Jesus, but an incarnation of the Word continues to be available to us in scripture. Scripture embodies in symbols and narratives the truth of the eternal Word." ${ }^{5}$ Also P. M. Blowers remarked about Maximus the Confessor: "clearly the "incarnation in the ancient figures of scripture does not lose its force after the historical person of Jesus, the timeless Logos being, as it were, simultaneously incarnate in creation/scripture/Jesus." 6

Furthermore, what concerns the case of Origen, G. Stroumsa, ${ }^{7}$ and, in the case of Augustine, C. W. Griffin and D. L. Paulsen ${ }^{8}$ have demonstrated that both Church Fathers worked out their theory and practice of an allegorical reading of the Scriptural texts, striving to overcome the views of Christians who believed that God had a humanlike shape. G. Stroumsa thus summarized the results if his research: "This type of intellectualist, aniconic mysticism has been characterized by G. Quispel as a Seinsmystic. Side by side with it, Quispel adds, there is long Christian tradition of a Gestaltmystic. For this kind of mysticism, God indeed does have a body (as the 'simple' anthropomorphists claim) but this body is visible only to the mystic. This mystical anthropomorphism is already attested in the Pseudo Clementine Homilies (17.7): God has a morphê, which only the pure of heart can see. The similarity of the doctrine of God's body in the Shi'ur Qomah fragments or in the Hekhalot Zutarti (where the mystic R. Aqiba is presented as their proponent) strongly suggests a Jewish

(3) D. BOYARIN, "Origen as theorist of Allegory: Alexandrian Contexts," in: The Cambridge Companion to Allegory, ed. R. COPELAND and P. T. STRUCK, Cambridge, 2010, p. 47.

(4) K. Froehlich, "'Take Up and Read.' Basics of Augustine's Biblical Interpretation," Interpretation: A Journal of Bible and Theology 58 (2004), p. 10.

(5) A. S. MilleR, "Philosophy and Scripture in Book VII of Augustine's Confessions," JCRT 7 (2005): 37.

(6) P. M. Blowers, Exegesis and Spiritual Pedagogy in Maximus the Confessor: An Investigation of the Quastiones ad Thalassium, Notre Dame, 1991, p. 124.

(7) G. StROUMSA, "The Incorporealty of God: Context and Implications of Origen's Position," Religion, 13 (1983), pp. 345-358.

(8) C. W. GRIFFIN and D. L. PAUlSEN, "Augustine and the Corporeality of God," HTR, 95 (2002), pp. 97-118. 
origin for this Gestaltmystic. It seems, indeed, that mystical anthropomorphism may have been an alternative solution to the... antinomy between 'simple' anthropomorphism and dualism - for a religious thought which did not, as did Alexandrian Christinaity, encounter Platonism." 9

Nevertheless, as D. J. Halperin has attempted to demonstrate, ${ }^{10}$ "Origen knew and drew upon a complex of homiletic exposition employed in third-century Cesarean synagogues on Shabu'ot (Pentecost), the festival believed to commemorate the Sinai revelation and the giving of the Torah." 11 This scholar has suggested that "Origen's assertion that the exiles "contemplated with the eyes of the heart" what Ezekiel "observed even with the eyes of the flesh" may reflect one of the goals of the Shabu' ot midrashim. The glory of God guarantees the authority of the Torah. The preacher's task is to expound this glory so vividly that the people can see it as if they were present at Sinai." 12 He added that "It is even possible that some Jews sought by magical means to see with their own eyes the things that Moses saw on his heavenly ascent. I very tentatively suggest that it may have been from their efforts that the Jewish ascension literature known as the Hekhaloth, to which Gershom Scholem has devoted so much attention, was born." ${ }^{13}$ At the same time, as Halperin noted, "Origen thoroughly Christianizes the Shabu'ot motifs. While he retains their link with the merkabah, he entirely severs their ties with Sinai. The ascending and triumphant Jesus replaces the ascending and triumphant Moses..."14 In this way, Origrn was familiar with the emerging teaching, which was in the process of a gradual formation in the Jewish mystic circles, and according to which the anthropomorphic Glory of God was implanted into the letters of the sacted text.

On the other hand, as Griffin and Paulsen suggested, Augustine formulated his teaching of the incorporeality of God within the framework of his theory of exegesis of the Scripture, containing the anthropomorphic descriptions of God, noting that "It is overly facile

(9) STROUMSA, “The Incorporealty of God," p. 353.

(10) D. J. HALPERIN, “Origen, Ezekiel's Merkabah, and the Ascension of Moses," Church History, 50 (1981), pp. 361-275.

(11) Ibid., p. 261.

(12) Ibid., p. 273.

(13) Ibid., p. 274.

(14) Ibid., p. 275. 
to say that precritical exegesis was a slave to theology, but it is true that certain theological principles inevitably lay at its foundations. Augustine himself articulates these principles in De doctrina christiana, a handbook for biblical exegesis and preaching. Ultimately, says Augustine, "the fulfilment and the end of the law and of all the divine scriptures is love," and any interpretation that does not build up the twin love of God and neighbour is flawed. He goes on to distinguish between literal and figurative expressions in scripture and gives clear criteria for distinguishing between them. "Anything in the divine writing that cannot be referred either to good, honest morals or to the truth of the faith, you must know is said figuratively." This is precisely the case with scriptural anthropomorphisms, since from Augustine's (incorporealist) perspective a literal reading of them contradicts the truth." 15

According to E. R. Wolfson, an allegorical interpretation of the scriptural anthropomorphisms was a characterististic feature of the rabbinic exegesis, to which the kabbalistic conception of the incorporation of limbs of the Divine Body in the letters of the Scripture is opposed. As this scholar expressed this his view, "...insofar as Torah is the name of $\mathrm{YHWH}$, and the latter takes the form of an anthropos..., it follows that each commandmend can be represented as a limb of the divine body. Such a perspective reverses the generally assumed allegorical approach to scriptural anthropomorphisms promoted by medieval rabbinic exegetes, for instead of explaining anthropomorphic characterizations of God as figurative way to accommodate human understanding, the attribution of corporeal images to an incorporeal God indicates that the real body, the body in its most abstract tangibility, is the letter..."16

On the other hand, D. Boyarin has noted a similarity of the mystical experience accompanying the process of the study of the sacred text, which occurred to Origen and the Rabbis interpreting the Torah, explaining that "For the Rabbis, what is found are the words themselves, as radiant, joyful, and sweet - no interpretations and no knowledge of truth - as when given on Mount Sinai; for Origen, it is not finally the words but the Word and with it the Truth that is to be located in the otherwise so kindred a spiritual practice of reading. For

(15) GRIFFIN and PAUlSEN, "Augustine and the Corporeality of God," pp. 110-111.

(16) WolfSOn, “The Body of the Text," pp. 490-491. 
Origen, those who find only words and enjoy the words remain irrational beasts and only those who strip the meaning of flesh off the bones of word and read the text in allegorical fashion, which means in Christ, could ever have hope for the experience of hot love that both he and his rabbinic interlocutor seek."17

Consequently, I would suggest that the Christian Church Fathers elaborated an allegorical method of interpreting the Bible, starting from an assumption that the Divine Logos is incorporated into the words of the Scripture and, probably, they even advanced a Christian version of the conception of the Book as the textualization of the Body, which does not contradict to an allegorical interpretation, but presupposes it. This supposition constitutes the main subject of this my article. This Christian conception of the textualization of the Body, as I will try to demonstrate, stems from the interpretation of the Transfiguration of Christ by Clement of Alexandria whose relevant texts contain the theme of the Name of God with related to it mysticism of letters with their numerological symbolism, and whose ideas, together with the exegetical conceptions, influenced the interpretation of the Transfiguration by other Christian authors. That the interpretation of Clement was not arbitrary but based on ancient themes inherent in the New Testament description of the Transfiguration can become clear, taking into consideration the work of C. Fletcher-Louis, ${ }^{18}$ who put the Synoptic account of the Transfiguration in the context of the heavenly ascent of Enoch and Moses, the motive of the service of the high priest in the Temple and the subordination of the theologia gloriae to theologia crucis.

\section{A) The Transfiguration OF CHRist AND A MYSTICAL CHRISTIAN ASCENT}

E. Wolfson begins his discourse with an indication on the ancient conception of the correlation between the letters of the sacred language and the creation of the world: "In one current of ancient Israel-

(17) BOYARIN, "Origen as theorist of Allegory," p. 54.

(18) C. FLETCHER-LouIS, "The Revelation of the Sacral Son of Man: The Genre, History of Religions Context and the Meaning of the Transfiguration," in: Auferstehung - Resurrection. The Fourth Durham-Tübingen Research Symposium Resurrection, Transfiguration and Exaltation in Old Testament, Ancient Judaism and Early Christianity, ed. F. AVEMARIE and H. LichtENBERGER, Tübingen, 2001, pp. 247-298. 
ite tradition, with roots stretching back to ancient Mesopotamia, wisdom was hypostasized or metaphorically depicted - there seems little sense to distinguish sharply between these options when assessing the scriptural context - as the first of God's creations, the idealized woman of valor and glory... By the later part of the Second Temple period, as is attested in a number of sources (for example, Sirach 24.9-13 and Baruch 3.36-4.4), the image of the fullness of primordial wisdom was identified by some as the Torah of Moses."19 Furthermore, "the sentiment well attested to in late antique Judaism that God created the world by gazing into the iscribed text of Torah in its primordial state can be viewed as an exegetical elaboration pieced together from several archaic theologoumena, including the demiurgical representation of divine wisdom, embracing, inter alia, the image of God's female playmate, visual figuration of the verbal icon of the will. The idea of a primordial text, the textulization of wisdom, resonates with a still older mythic notion of the heavenly tablets that bear the divine inscription whence the visionary-sage learns the secrets of the cosmos, history, and time..."20

Very similar ideas can be found in the writings of an early Christian author Clement of Alexandria (c. 150-215).

And if the tables that were written were the work of God, they will be found to exhibit physical creation. For by the "finger of God" is

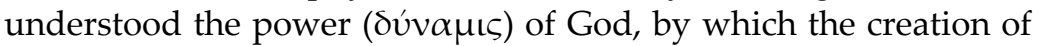
heaven and earth is accomplished; of both of which the tables will be understood to be symbols. For the writing and handiwork of God put on the table is the creation of the world. And the Decalogue, viewed as an image of heaven, embraces sun and moon, stars, clouds, light, wind, water, air, darkness, fire. This is the physical Decalogue of the heaven. And the representation of the earth contains men, cattle, reptiles, wild beasts; and of the inhabitants of the water, fishes and whales; and again, of the winged tribes, those that are carnivorous, and those that rise mild food; and of plants likewise, both fruit-bearing and barren. This is the physical Decalogue of the earth. And the ark which held them will then be the knowledge of divine and human things and wisdom (бoфí $\alpha) .{ }^{21}$ (Stromata VI, cap. XVI, 133, 1-3)

(19) Wolfson, "The Body of the Text," p. 483.

(20) Ibid., pp. 484-485.

(21) The Writings of Clement of Alexandria, tr. W. WILSON, vol. II, Edinburgh, 1869 , p. 383 


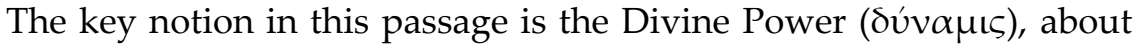
which G. Quispel remarked that "Gershom Scholem, in his Jewish Gnosticism (67) has shown convincingly that Geburah or Dynamis was an appellative or metonym of the divine Glory among the apocalypticists. This esoteric use continued in the circles of Mekabah mystics." 22 Moreover, Scholem has suggersted that "Geburah, or 'Dynamis,' was an appelative or metonym of 'The Divine Glory' among the apocalypticists, and with this very meaning entered the Gospels in the famous passage: 'You shall see the Son of Man seated at the right hand of the Dynamis' [Matthew 26:64; Mark 14:62]."23

Clement of Alexandria has interpreted the Transfiguration of Christ as the disclosure of the divine "Dynamis," and he used for his interpretations the elements of the Merkabah mysticism, which can be made evident in the analysis of the text from Stromata VI. Cap. XVI. 140, 2-4:

And they (the Pythagoreans) call eight a cube, counting the fixed sphere ( $\tau \dot{\eta} \nu \alpha \pi \lambda \alpha v \tilde{\eta})$ along with the seven revolving ones, by which is produced "the great year," as a kind of period of recompense of what has been promised. Thus the Lord, who ascended the mountain, the fourth, becomes the sixth, and is illuminated all

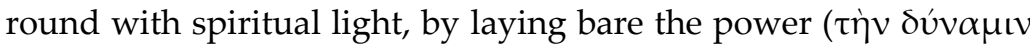
$\left.\tau \eta \dot{\nu} \nu \alpha \pi^{\prime} \alpha \dot{v} \tau o \tilde{v} \pi \alpha \varrho \alpha \gamma v \mu \nu \omega \sigma \sigma \alpha \varsigma\right)$ proceeding from Him, as far as those selected to see were able to behold it, by the Seventh, the Voice, proclaimed to be the Son of God; in order that they, persuaded respecting Him, might have rest; while He by His birth,

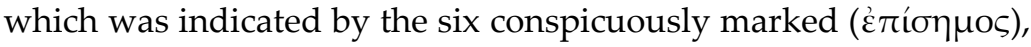
becoming the eighth, might appear to be God in a body of flesh, by displaying His power ( $\delta \dot{v} v \alpha \mu \nu$ ), being numbered indeed as a man, but being concealed as to who He was. For six is reckoned in the order of numbers, but the succession of the letters acknow-

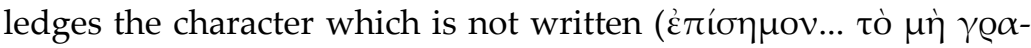
$\phi$ ó $\mu \varepsilon v o v) .{ }^{24}$

(22) G. QUISPEL, "Ezekiel 1:26 in Jewish Mysticism and Gnosis," VC, 34 (1980), pp. 9-10. As it has been demonstrated by J. Fossum, the name of "the (Great) Power" applied to Christ by Jewish Christians is also one of the names of Metatron in the Hekaloth literature J. Fossum, "Jewish-Christian Christology and Jewish Mysticism," VC, 37 (1983), pp. 272-273.

(23) G. SCHOLEM, Jewish Gnosticism, Merkabah Mysticism, and Talmudic Tradition, New York, 1965, p. 67.

(24) The Writings of Clement of Alexandria, tr. WILSON, vol. II, pp. 387-388. 
As it has been argued by A. Méhat, in this text Clement modified an arithmological teaching of Gnostics which he could find in Irenaeus. ${ }^{25}$ To this one might add that in Adv. Haer. I. XIV.4 Irenaeus explains

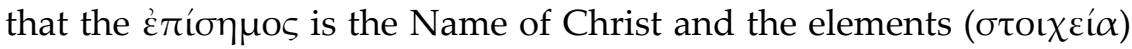
of which it consists are the letters, which have also the numerical meaning.

When she (the Tetrad) had spoken these things, Aletheia looked at him, opened her mouth, and uttered a word. That word was a name, and the name was this one which we do know and speak of, viz., Christ Jesus. When she had uttered this name, she at once relapsed into silence. And as Marcus waited in the expectation that she would say something more, the Tetrad again came forward and said, "Thou hast reckoned as contemptible that word which thou hast heard from the mouth of Aletheia. This which thou knowest and seemest to possess, is not an ancient name. For thou possessest the sound of it merely, whilst thou art ignorant of its power. For Je-

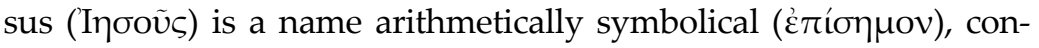
sisting of six letters, and is known by all those that belong to the called. But that which is among the Aeons of the Pleroma consists of many parts, and is of another form and shape, and is known by those [angels] who are joined in affinity with Him, and whose figures (mightinesses) are always present with Him. ${ }^{26}$

As it is indicated by the parallel constructions in Clement's text

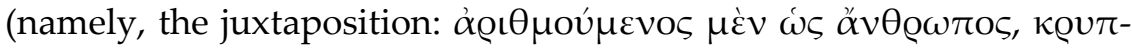

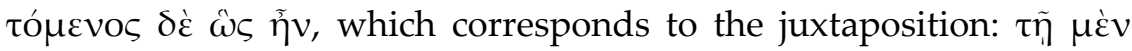

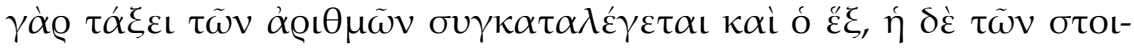

(25) "En general, sur les points de doctrine, la pratique des dogmata lui sert de guide, et je ne crois pas qu'on puisse le trouver en contradiction avec les siens, même pour les raisons d'oiconomia. Mais dans le detail, les réutilisations de données provenant des hérétiques abondent. Ainsi Clément trouve, sans doute chez Irénée, une intertrétation arithmologique de la pericope de la transfiguration; il la transpose, en modifiant d'ailleure subtilement le sens." (A. MÉHAT, "Vraie' et 'fausse' gnose d'après Clément d'Alexandrie," in: The Rediscovery of Gnosticism. Proceedings of the International Conference on Gnosticism at Yale, 1978, I: The School of Valentinus, ed. B. LAYTON, Leiden, 1980, p. 430.)

(26) The Writings of Irenaeus, tr. by A. ROBERTS and W. H. RAMBAUT, vol. I, Edinburgh, 1868, pp. 59-60. 


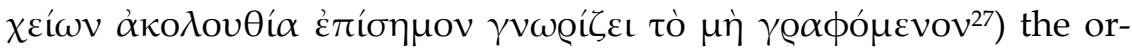
der of numbers is connected with the humanity of Christ (and also with the created universe) while the sequence of letters of the Name is connected with His divinity. This passage contains also the theme of the mystical ascent of Christians, while God reveals Himself to

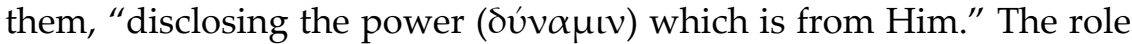

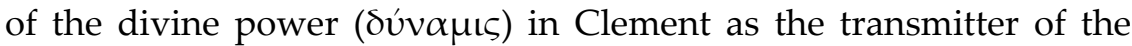
knowledge coming through the Son-Logos has been demonstrated by D. T. Runia. ${ }^{28}$ According to Clement, this "dynamis" is disclosed by

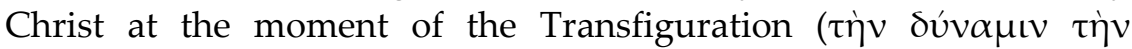

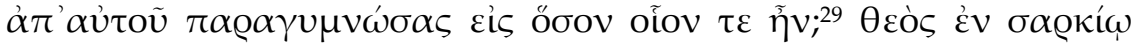

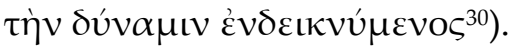

Concrete contents of the knowledge transmitted by Son-Logos at

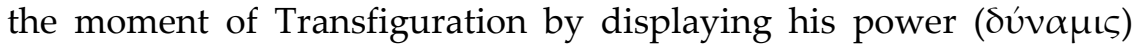
can be clarified on the basis of some of the findings contained in the work of Fletcher-Louis who has demonstrated that the account of the Transfiguration comprises the mythology of the Mount Hermon, connected with the fall of the watches. According to this scholar, in some of the sources Hermon is associated with Lebanon and the Jerusalem Temple, and "This identification is also assumed in the tying of the myth of the fall of the watches to the ritual of the Day of Atonement: at Yom Kippur the priesthood somehow re-enacts and actualizes God's punishment of the watches at Hermon." 31

On the other hand, A. Orlov ${ }^{32}$ discerned in the stories, contained in various ancient and medieval sources, the survival of the motive of Enoch/Metatron' role in the invention of the art of writing and the transmission of the secrets of astronomical calculations. These stories

(27) Clemens Alexandrinus, Zweiter Band. Stromata. Buch I-VI, hg. O. STÄHLIN und L. FRÜCHTEL (Die Griechischen Christlichen Schriftsteller der ersten Jahrhunderte, 52 [15]), Berlin, 1960, S. 503.16-19.

(28) D. T. RUNIA, "Clement of Alexandria and the Philonic Doctrine of the Divine Power(s)," VC, 58 (2004), pp. 256-276.

(29) Clemens Alexandrinus, Zweiter Band. Stromata. Buch I-VI, hg. STÄHLIN und FRÜCHTEL, S. 503.12-13.

(30) Ibid., S. 503.16.

(31) Fletcher-LOUIS, "The Revelation of the Sacral Son of Man," p. 270.

(32) A. ORLOV, “Overshadowed by Enoch's Greatness: 'Two Tablets' Tradition from the Book of Giants to Palaea Historica," in: IDEM, From Apocalypticism to Merkabah Mysticism: Studies in the Slavonic Pseudepigrapha, Leiden, Boston, 2007, pp. 109-131. 
tell about an attempt at the salvation of humanity from the destuction by flood or fire made by Seth and his progeny, Enosh or Noah by means of erecting two pillars (or tablets) of brick and of stone, with inscribed on them discoveries. These stories include Noah's unsuccessful preaching to the Giants, which can correspond to Enoch's preaching to the Watchers/Giants in order to prevent their destruction due to their sinful behaviour. As A. Orlov noted, "...the prototype of the story was connected with the Watches's and Enoch's preaching to them. Several details in the texts point to this connection. First, History of the Forefathers 45 defines the number of "the sons of God" as two hundred. In the Enochic traditions this numeral appears often in reference to the number of the Watches who descended on Mount Hermon." 33

In this way, since Fletcher-Louis connected the glorous transformation of Christ in the moment of the Transfiguration with Enoch as angelomorphic and Divine mediator, ${ }^{34}$ the knowledge transmitted by Son-Logos at the moment of Transfiguration, in the compre-

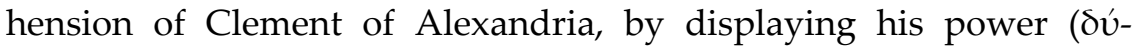
$v \alpha \mu \iota \varsigma)$, can consist of the revelation of some heavenly arithmetical and astromomical secrets.

This revelation can be related to the disclosing of the symbolism of the "fourth," because, while the "sixth" is associated with the name "Jesus" (which implies the theme of the Incarnation), the "fourth" is apparently connected with the Name of God accessible to those who enter the inner sanctuary (adyton).

Again, there is the veil $(\pi \alpha \varrho \alpha \pi \varepsilon \dot{\tau} \alpha \sigma \mu \alpha)$ of the entrance into the holy of holies. Four pillars there are, the sign of the sacred tetrad of the ancient covenants. Further, the mystic name of four letters

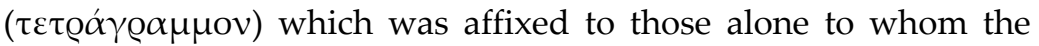
adytum was accessible, is called Jave, which is interpreted, "Who is and shall be." The name of God (Өcós), too, among the Greeks contains four letters. ${ }^{35}$ (Stromata V, ch. VI, 34, 4-6)

These ideas of Clement, probably, witness about the survival of the ancient Judaeo-Christian Christology where Christ was considered as sharing the common name with the Father, the Tetragrammaton

(33) ORLOV, “Overshadowed by Enoch's Greatness," p. 120.

(34) Fletcher-Louis, "The Revelation of the Sacral Son of Man," pp. 249-250.

(35) The Writings of Clement of Alexandria, tr. WILSON, vol. II, p. 241. 
("YHWH"). ${ }^{36}$ C. A. Gieschen has indicated on the Jewish antecedents of this theological concept as $\mathrm{YHWH}$ appearing as an angel and as a divine hypostasis dwelling in the temple. ${ }^{37}$ According to this scholar, "a similar tradition is found in 3 Enoch, a fifth or sixth century CE Jewish mystical text preserved in Hebrew that purports to be a record of the mystical ascent vision of Rabbi Ishmael, one of the secondgeneration Tannaim (120-140 CE). 3 Enoch contains an account that depicts "the Holy One" (God) writing "the letters by which heaven and earth were created" upon a crown (13.1) that he places upon Metatron:

[12.5] He set it upon my head and he called me, "the lesser YHWH" [יהוה הקטץ] in the presence of his whole household in the height, as it is written, "My name is in him."

The overt reference to Exod 32.31 demonstrates the ongoing influence of this tradition: Metatron is depicted as the theophanic angel who possesses the Divine Name that is responsible for all creation and is even called "the Lesser YHWH." 38

Furthermore, the numerological symbolism in connection with the

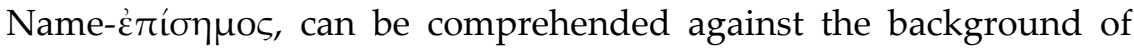
indicated by G. Stroumsa common features of Metatron in the Shi'ur Quomah and Christ in the Valentinian Gnostic teaching (which can be explained by their common origin in Jewish Christianilty ${ }^{39}$ since one of these features is the juxtaposision of the name consisting of twenty-four letters with a name consisting of six letters (mttrwn in Shi'ur Quomah and $\iota$ roov in Marcos Gnosticos). ${ }^{40}$

As C. Fletcher-Louis has indicated, the theme of the Name of God is indirectly implied in the Synoptic account of the Transfiguration. According to this scholar, in the Gospel of Thomas, "...when Jesus takes Thomas aside to give him a special revelation he utters three words. What were these words? They are best explained as the three words of the divine Name revealed to Moses in Exodus 3:14: אשר אהיה אהיה. If Thomas were to pronounce these three words to

(36) C. A. GIESCHEN, "The Divine Name in Ante-Nicene Christology," VC, 57 (2003), pp. 115-158.

(37) Ibid., pp. 121-123.

(38) Ibid., p. 126.

(39) G. Stroumsa, "Form(s) of God: Some Notes on Metatron and Christ," HTR, 76 (1983), pp. 281-287.

(40) Ibid., p. 281. 
his fellow disciples he might justly be stoned for blasphemy. Jesus thus behaves as though he is the Angel of the LORD and Thomas as Moses at the burning bush. But Jesus' annunciation of the unspeakable Name gives him a position otherwise reserved for the high priest. In the synoptic Transfiguration there is no explicit mention of the divine Name. However, it is probable that here again the Gospel of Thomas is engaging in one-up-manship with the Peter of the synoptics. In Matthew 14:22-33 Jesus walks to the disciples on the water. In doing so he speaks the divine Name ( $\dot{\gamma}(\omega) \varepsilon \dot{\mu} \mu)$ and Peter follows him in his ability to overcome the normal properties of water. Where Matthew has Peter take up the theurgic power of the one who can speak the divine Name..., in the extra-canonical gospel it is Thomas who has priviledged access to the Name." 41

The themes of the Divine Name and the Dynamis are present in a controversial passage from the Excerpta ex Theodoto (Section A, 27, 1-6), in which the themes of the sanctuary of the temple, the spiritual ascent of a Christian soul and the Name of Christ are intricately interlaced.

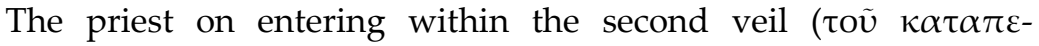

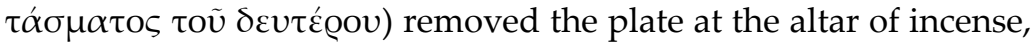
and entered himself in silence with the name engraved ( $\dot{\gamma} \gamma \kappa \varepsilon-$ $\chi \alpha \varrho \alpha \gamma \mu \varepsilon ́$ vov) upon his heart, indicating the laying aside of the body which has become pure like the golden plate and bright through the purification of the soul and on which was stamped ( $\dot{\gamma} \gamma \varepsilon \varepsilon \chi \alpha \dot{\alpha} \propto \alpha \kappa \tau)$ the lustre of piety, by which he was recognized by the Principalities and Powers as having put on the Name. Now he discards his body, the plate which has become light, within the second veil, that is, in the rational sphere, the second complete veil of the universe, at the altar of incense, that is, near the angels who are the ministers of the prayers carried aloft. Now the soul, stripped ( $\gamma \nu \mu \nu \eta$ ) by the power of him who has knowledge, as if it had become a body of the power ( $\sigma \omega \mu \alpha \tau \tilde{\eta} \varsigma \delta v v \alpha \dot{\mu} \mu \varepsilon \omega \varsigma)$, passes into the spiritual realm and becomes now truly rational and high priestly, so that it might now be animated, so to speak, directly by the Logos, just as the archangels become the high-priests of the angels and the first-created the high-priests of the archangels. But how can there be a correction ( $\kappa \alpha \tau o ́ \varrho \theta \omega \mu \alpha$ ) produced by Scripture and apprehension for the soul which has become pure, when it is granted to see God "face to face"? Thus, having transcended the

(41) Fletcher-LouIs, "The Revelation of the Sacral Son of Man," p. 297. 
angelic teaching and the Name taught in Scripture, it comes to the knowledge and comprehension of the facts ( $\varrho \alpha \gamma \mu \alpha \alpha \tau \omega \nu)$. It is no longer a bride but has become a Logos and rests with the bridegroom together with the first-called and first-created, who are friends by love, sons by instruction and obedience, and brothers

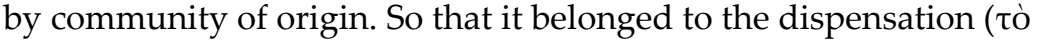
$\mu \dot{\varepsilon} \nu \tau \tilde{\eta} \varsigma$ oikovouí $\alpha \varsigma$ ) to wear the plate and to continue the pursuit

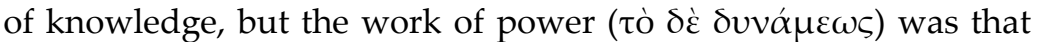
man becomes the bearer of God, being controlled directly by the Lord and becoming, as it were, his body. ${ }^{42}$

This passage was analysed by S. Lilla who wrote: "The scholars who have examined or translated this paragraph of the Excerpta have regarded it as belonging to Clement. The paragraph contains, however, some ideas which fit much better the way of thinking of a Gnostic author." 43 And further this scholar continues his argumentation provided by the parallels from the texts of (mostly) Valentinian Gnostics attempting at demonstrating that "it is far more likely that this paragraph of the Excerpta belongs to a gnostic writer (perhaps to Theodotus himself) rather than to Clement." 44

However, it seems that this passage rather represents a modification of the Gnostic teaching in a similar way as the passage treating the numerology of the Transfiguration. First, the passage from the Excerpta ex Theodoto, like the previously discussed one, seems to contain two interrelated themes, that of the ascent of Christ and the idea that the ascent of a Christian soul is the work of His power

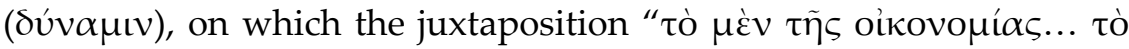
$\delta \dot{\varepsilon} \delta v v \alpha \dot{\mu} \mu \omega \varsigma^{\prime \prime}$ at the end of the passage from the Excerpta seems to indicate.

The theme of Christ as High Priest entering the heavenly Tabernacle evokes a detailed account of this theme in the Hebrews Epistle (Hebr. 5; 7; 9), where this heavenly priestly service of Christ, juxtaposed to the earthly service of Old Testament priests is presented as a kind of a typological exegesis of Christ's Ascension. It has been demonstrated by $\mathrm{H}$. Riesenfeld that several important theological themes implied in the Gospel account of the Transfiguration of Christ

(42) The translation is by R. P. CASEY, revised by S. LILLA, Clement of Alexandria: A Study in Christian Platonism and Gnosticism, Oxford, 1971, p. 176.

(43) LILlA, Clement of Alexandria, pp. 176-177.

(44) Ibid., p. 179. 
have parallels in the Hebrews Epistle, and primary the theme of priestly dignity of the Messiah. ${ }^{45}$ Moreover, to the comprehension of the Clement's text are also relevant the connections and similarities between Philo and the Hebrews Epistle. In the Hebrews Epistle Christ is called "high priest after the order of Melchisedec" (5:10; 7:3). Philo calls the logos the high priest (e.g. De Fuga et Inventione, 108; De Migratione Abrahami 102), and Melchisedec is considered as an allegorical representation of the logos (e. g. Legum Allegoriarum, 3.82). ${ }^{46}$

A sentence from the Excerpta (Thus, having transcended the angelic teaching and the Name taught in Scripture, it comes to the knowledge and comprehension of the facts $(\pi \varrho \alpha \gamma \mu \alpha \dot{\tau} \tau \omega v)$ ), as it seems, implies a reference to Hebr 10:1 "For the law having a shadow

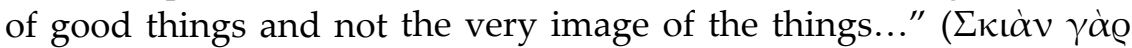

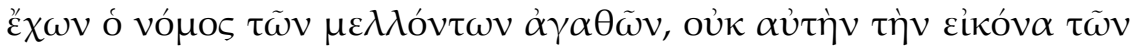
$\pi \rho \alpha \gamma \mu \alpha \dot{\tau} \tau \nu \ldots)$, in general conformity with the ascent of Christ to the heavenly, not-made-with-hands tabernacle (Hebr 9:23-28). The themes of the tabernacle in connection with the notions of the "image" and "shadow," employed by the author of the Hebrews Epistle, can be found in Philo, for whom, as it was discussed by W. Williams, the "...aerial/psychic body signified by the blue robe is in some way related to... designation of the demiurgic Logos as both God's Image and 'Shadow' (Leg. III.96). Philo identifies the Logos with Bezalel ('In the Shadow of God'), chief craftsman of the Tabernacle and its works according to Exod. 31:2ff." ${ }^{47}$ Within this frame of reference, it seems that the author of the Hebrews Epistle designates the liturgy in the heavenly Tabernacle completed by risen Christ-Logos as the "Image," while the tabernacle built by Moses and the service in it as the "Shadow." This supposition can be confirmed as well by the reference to

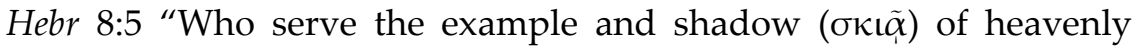
things, as Moses was admonished of God when he was about to make the tabernacle: for, See, saith he, that thou make all things according to the pattern showed to thee in the mount."

(45) H. RIESENFELD, Jésus transfuré. l'arrière-plan du récit évangélique de la transfiguration de Notre-Seigneur, Copenhagen, 1947, pp. 266-274.

(46) D. T. RuniA, Philo in Early Christian Literature: A Survey, Minneapolis, 1993, p. 77; K. SCHENK, A Brief Guide to Philoi, Westminster, 2005, p. 83

(47) W. WILLIAMS, THE SHADOW OF GOD. Speculations on the Body Divine in Jewish Esoteric Tradition, on-line <http://www.theblackgod.com/Shad ow\%20of\%20God\%20Short\%255B1\%255D.pdf $>$. 
Furthermore, in a passage from the Excerpta under consideration the Name, engraved in the heart of the Great Priest indicates on the connection of this passage with the discussed above text about the

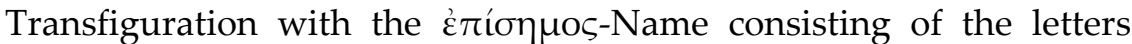
with numerical meaning. These themes from the Pauline Epistles were put by C. A. Gieschen in the context of his analysis of the role of the Name (Tetragrammaton) in the early Christology inherited from its role in the Old Testament. ${ }^{48}$ Although Gieschen completed his article by the quotation from the Stromata of Clement of Alexandria, demonstrating that this Old Testament theme survived till Clement's interpretation (in which he followed Philo) of the golden plate of the High Priest as the Name, the discussed passage from the Excerpta ex Theodoto (Section A, 27,1-6) about the High Priest with the Name engraved in his heart in the Holy of Holies fits even better the tradition described by Gieschen, comprising the theophanic appearance of the Name as an angel and the dwelling of the Name in the Temple.

The theme of the Name engraved in the heart of the High Priest has a parallel in a Jewish Merkabah literature in the theurgic context, discovered by Scholem: "In the Midrash Tehillim, R. Levi says: 'A tablet with the name of the Holy One, blessed be He, is engraved on the hearts of the angels as a sort of mark [asteriscus]'." 49 The same motive can be found in Pesikta de Rav Kahana: "Resh Laqish said: There is a tablet upon the heart of every angel and the name of the Holy One, blessed be he, is engraved on it, together with that of the angel - Michael, Gabriel, Raphael" (Pesiqta' de RabKahana 12:22). ${ }^{50}$

On the other hand, an observation of G. Quispel can support the idea that Clement's conception of the "name engraved upon" the heart of the priest presupposes the interchageability of the notions of the Name and the Logos. "The Didache $(10,2)$ speaks about the 'Name, which thou madest dwell (kateskēnōsas) in our heart'... The expression has parallels in Jewish literature. In the Psalms of Solomon it is said: 'we will find mercy, when your Name dwells (kata-

(48) Gieschen, “The Divine Name," pp. 128-131.

(49) SCHOLEM, Jewish Gnosticism, p. 71. Scholem used a translation of W. G. BRAUdE, Midrash on Psalms, New Haven, 1959, which he has corrected.

(50) Pesikta de Rav Kahana, according to an Oxford manuscript, with variants from all known manuscripts and genizoth fragments and parallel passages, with commentary and introduction, ed. B. MANDELBAUM, New York, 1987, p. 221. Tr. by P. AleXANDER in: The Old Testament Pseudepigrapha, ed. J. H. CHARLeSWORTH, vol. 1, New York, London, 1983, p. 284, n. 30d. 
skēnoun) among us' (7:6). This of course is the best imaginable parallel for John 1:14: 'the Word became flesh; he came to dwell among us'; it shows how Jewish is the wording of John and how close are the meanings of Logos and Onoma." 51

Following Quispel, J. Helderman adduced Phil 2:6-11 as an evidence of the New Testament reflection on the Jewish esoteric teaching where the Word of God was identified with the Name of God, which can be traced as well in the Hermetic Poimandres and in Philo. ${ }^{52}$ This idea expressed by Philo can be found in On Confusion of the Tongues 146.

But if there be any as yet unfit to be called a Son of God, let him press to take his place under God's First-born, the Word, who holds the eldership among the angels, their ruler as it were. And many names are his, for he is called, "the Beginning," and the Name of God, and His Word, and the Man after His image, and "he that sees," that is Israel. ${ }^{53}$

The second part of Clement's passage from the Excerpta ex Theodoto, treating the ascent of the soul divinised by the Logos seems as well to be implied in the ideas of Philo expressed in De sacrificiis Abelis et Caini 8.

A further thought of the same nature is revealed to us... There are still others, whom God has advanced even higher, and has trained them to soar above species and genus alike and stationed them beside himself. Such is Moses to whom He says "stand here with $\mathrm{Me}^{\prime \prime}$ (Deut. V. 31). And so when Moses was about to die we do not hear of him "leaving" or "being added" like those others. No room in him for adding or taking away. But through the 'Word' of the Supreme Cause he is translated (Deut. xxxiv. 5), even though that Word by which also the whole universe was formed. Thus you may learn that God prizes the Wise Man as the world, for that same Word $(\tau \tilde{\omega} \alpha \dot{v} \tau \tilde{\omega} \lambda o ́ \gamma \omega)$, by which He made the universe, is

(51) G. QUISPEL, Gnostic Studies, Istanbul, 1974-1975, vol. II, p. 228.

(52) J. Helderman, "Licht, Leben and das Wort," in: Die Hermetische Gnosis in Lauf der Jahrhunderte, ed. G. QuISPEL, Haarlem, Birnbach, 2000, pp. 276-278.

(53) Translation by COLSON, cf. Philo, vol. IV, Cambridge, 1932, pp. 8991 (COHN-WendLAND, Vol. II, p. 257). 
that by which he draws the perfect man from things earthly to Himself. ${ }^{54}$

M. Barker has noted that Clement put the theme of the ascent of the soul into the context of the apocalyptic reinterpretation of temple imagery: "Clement knew the temple setting of the apocalyptic tradition; it is no accident that the image of the high priest's entering the holy of holies was used to describe the Gnostic entering the state of knowledge. The high priest's golden plate represented his body which he left behind when he entered the holy of holies, said Clement's Theodotus. Thus he passed through the veil which represented the intelligible world and the world beyond." 55

This scholar has analysed the significance of this apocalyptic veil in detail, describing it in the following way: "Philo says that the veil 'separated the changeable parts of the world... from the heavenly region which is without transient events and is unchanging' (Questions on Exodus 2.91). The best known example of a timeless experience is the vision of Jesus in the wilderness when he was taken to a high place and saw 'all the kingdoms of the world in a moment of time' (Luke 4.5). In the Apocalypse of Abraham the patriarch was taken up to heaven where he saw the stars far below him (Ap. Abr. 20.3). The Eternal One then said to him: 'Look now beneath your feet at the firmament and understand the creation that was depicted of old on this expanse...' (Ap. Abr. 21.1). Abraham sees the firmament as a screen on which the history of his people is revealed to him. The detail which links this experience of the firmament to the holy of holies is to be found in 3 Enoch, an undateable text which describes how Rabbi Ishmael the high priest ascended to heaven. Now Rabbi Ishmael lived after the temple had been destroyed and cannot have been a high preist, and the versions of 3 Enoch which we have were compiled long after that. Nevertheless, the association of ascent, high priesthood and the sanctuary experience persisted, and thus we find in 3 Enoch the explanation of the vision described in the Apocalypse of Abraham. The firmament is the veil.

(54) Translation by Colson, cf. Philo, vol. II, Cambridge, 1929, pp. 99101 (COHN-WENDLAND, vol. I, p. 205).

(55) M. BARKER, The Great High Priest: the Temple Roots of the Christian Liturgy, Edinburgh, 2003, pp. 6-7. 
In 3 Enoch, R. Ishmael ascended to heaven and met Metatron, the great angel who in his earthly life had been Enoch, and who became his guide:

Metatron said to me: Come, I will show you the veil of the All Present One, which is spread before the Holy One, blessed be He, and on which are printed all the generations of the world and all their deeds, whether done or yet to be done, until the last generation. I went with him and he pointed them out to me with his fingers, like a father teaching his son (3 En. 45).

The visionary saw history depicted on the veil, on the other side, so to speak, of matter and time." ${ }^{56}$

Moreover, M. Barker has indicated on the connection of this motive with the Christological interpretation of this cosmic curtain in the Hebrews Epistle, pointing out that "the veil was the boundary between earth and heaven. Josephus and Philo agree that the four different colours from which it was woven represented the four elements from which the world was created: earth, air, fire and water. The scarlet thread represented fire, the blue was air, the purple was the sea, i. e. water, and the white linen represented the earth in which the flax had grown (War 5.212-213). In other words, the veil represented matter. The high priest wore a vestment woven from the same four colours and this is why the Book of Wisdom says that Aaron's robe represented the whole world (Wisdom 18.24; also Philo, Laws 1.84; Flight 110). He took off this robe when he entered the holy of holies because the robe was the visible form of one who entered the holy of holies. In the Epistle to the Hebrews, which explores the theme of Jesus as the high priest, there is the otherwise enigmatic line: his flesh was the veil of the temple (Heb 10:20). In other words, the veil was matter which made visible whatever passed through it from the world beyond the veil. Those who shed the earthly garments, on the other side of the veil, were robed in garments of glory." 57

In the Hebrews Epistle, as it was summurized by S. D. Mackie," the author recounts the high priest's yearly entry 'though the second veil

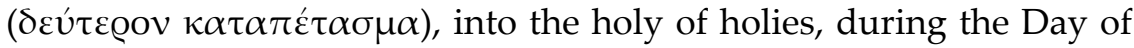
Atonement, and adversely juxtaposes this tentative and limited access with Jesus' triumphant and conclusive entry into the heavenly

(56) BARKER, The Great High Priest, pp. 192-193.

(57) Ibid., p. 190. 
holy of holies (9.11-14). Most significantly, as a consequence of Jesus' entry and occupation of the heavenly holy place, in 6.18-20 the community ('those who have taken refuge') is 'strongly encouraged ( $ڤ \sigma \chi v \varrho \alpha \dot{v} \pi \alpha \varrho \alpha ́ \kappa \lambda \eta \sigma \iota v)$ to seize the hope set before us', which is 'a sure and steadfast anchor of the soul', and which 'enters the inner shrine behind the veil ( $\kappa \alpha \tau \alpha \tau \varepsilon \dot{\tau} \tau \alpha \sigma \mu \alpha)$, where Jesus, the forerunner on our behalf, has entered'." 58 In this way, the conception of the "second complete veil of the universe," used by Clement in the dicussed passage, as clearly connected with the adduced above apocalyptic Jewish and Jewish-Christian theological conceptions.

The same can be said about the conception of the "putting on the Name," possible Jewish or Judaeo-Christian origin of which was discovered by G. Quispel, ${ }^{59}$ who came to this conclusion by assuming the common root for this motive in the Valentinian Gnostics, Samaritan heterodox Jews, the author of the Odes of Solomon, and magical Jewish writings of later date. ${ }^{60}$ Moreover, as A. D. De Conick noted, "luminous anthropomorphic descriptions of the "Hidden" God are the culmination of many of the stories of the heroes who journey to glimpse Yahweh enthroned. A cluster of images are found in these descriptions. His body is enrobed in a splended white garment with a face emitting sparks. The haluq, or robe, is described as most holy, frightful and terrible, emitting tremors, terror, and vibration. Upon the inside and outside of the garment, from the top to the bottom, the tetragrammaton is etched." ${ }^{11} \mathrm{G}$. Scholem assumed that this garment is 'cosmic', because "in the other two hymns in which the garment is mentioned its cosmic function is clearly indicated." 62 In the Chapter 4:2 of the Greater Hekhaloth, as Scholem writes, "we learn that the stars were created by the light that issues from His Haluk. Nor is this just a poetic façon de parler, but it connects well with the Aggadah told by R. Samuel. God wrapped Himself in this garment in the hour of

(58) S. D. MACKIE, “Ancient Jewish Mystical Motifs in Hebrews' Theology of Acceess and Entry Exhortations," New Testament Studies, 58 (2012), pp. 93-94.

(59) GIESCHEN, “The Divine Name,” pp. 119-120.

(60) QuisPeL, Gnostic Studies, vol. I, p. 208-209; vol. II, p. 226-229.

(61) A. D. DECONICK, "What is Early Jewish and Christian Mysticism?" in: Paradise Now: Essays on Early Jewish and Christian Mysticism, Leiden, 2006, pp. 15-16.

(62) SCHOLEM, Jewish Gnosticism, p. 60. 
creation just as He does every time He steps down to sit on His throne." 63

Scholem has indicated on "the presence of obviously Jewish elements of esoteric teaching in the Excerpta ex Theodoto" which, according to him, "has here been partly misunderstood or reinterpreted and partly put into false contexts." 64 However, one may note that both the cosmic garment interwoven with the Name and the cosmic veil are present in a discussed passage in the Excerpta ex Theodoto (Section A, 27,1-6), only they function there, as it seems, not as "a deterioration of the Jewish tradition," 65 but as the Christological reinterpretation of similar tradition, which can be supported by other New Testament (mostly hymnic) references to the Ascension of Christ involving the theme of the Name. In Phil. 2: 9-10 one reads: "Wherefore God also hath highly exalted him, and given him a name which is above every name; That at the name of Jesus every knee should bow, of things in heaven, and things in earth, and things under earth." In Eph. 1:19-21

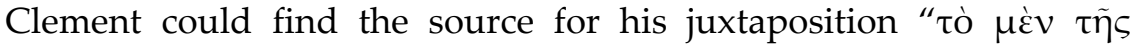

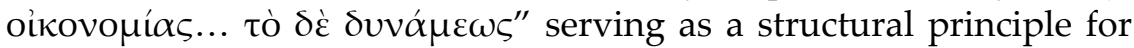
the whole passage: "And what is the exceeding greatness of his power ( $\tau \tilde{\eta} \varsigma \delta v v \alpha ́ \mu \varepsilon \omega \varsigma)$ to us-ward who believe, according to the working of his mighty power, which he wrought in Christ, when he raised him from the dead, and set him at his own right hand in the heavenly places, far above all principality, and power, and might, and domin-

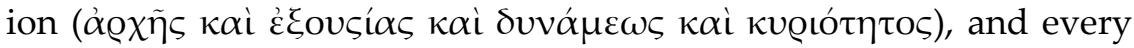
name that is named..." The last phrases seem to correlate with the Clement's text: "...the purification of the soul and on which was stamped ( $\dot{\gamma} \gamma \kappa \varepsilon \chi \alpha \dot{Q} \alpha \kappa \tau)$ ) the lustre of piety, by which he was recog-

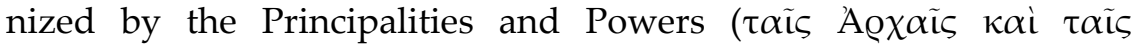

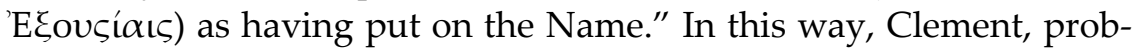
ably, interprets Metatron or Philo's Logos as Christ ascending beyond the impenetrable cosmic veil, acquiring Himself the cosmic garment, that is, putting on the Name, and, even more than this, opens this way to the entirely purified and edified Christian souls.

On the other hand, the motive of the soul, stripped ( $\gamma v \mu v \eta$ ) by the power of him who has knowledge and passing into the spiritual realm may represent a Clement's elaboration of the themes contained

(63) SCHOLEM, Jewish Gnosticism, p. 61.

(64) Ibid., p. 34.

(65) Ibid. 
in the controversial interpretation of the sayings of Jesus in different trajectories, studied by J. M. Robinson, ${ }^{66}$ of which, as it was demonstrated by this scholar, in the Gnostic circles there was a tendency to attribute the explicit interpretation of the parables and riddles to the risen Christ. One example adduced by Robinson is particularly relevant for the understanding of the passage from Excerpta ex Theodoto A, 27. "Irenaeus accuses the Valentinians of this two-level interpretation of Jesus' sayings, making use of this fluid technical terminology (1.1.5): "They tell us, however, that this knowledge has not been openly [phanerōs] divulged, because all are not capable of receiving it, but has been mystically revealed by the Savior through means of parables to those qualified for understanding it." Thus when Morton Smith sees a "libertine" implication in an excerpt from the Valentinian Theodotus quoted by Clement of Alexandria and ascribed by Smith to a pre-Marcan Aramaic gospel, a much less exciting, indeed pedantic but methodologically more reliable interpretation would be to the effect that again one has (here divided into three progressive levels) the same contrasting hermeneutic pair expressed in a series of synonyms: "The Saviour taught the Apostles at first figuratively and mystically, later in parables and riddles, and thirdly clearly and openly [as R. P. Casey freely but accurately translates gymnōs, in this context as a synonym for parrhessia, but which Smith translates literally but tendentiously as 'nakedly'] when they were alone..."67

However, to this might be added that, although the word "gymnōs" is to be understood as "openly," the literal meaning of this word seems to be also present, not in the sense attributed to it by Smith, but as it functions in the Logion 37 of the Gospel of Thomas, analysed in detail and put into context by A. D. De Conick and J. Fossum. ${ }^{68}$ This Logion reads: "His disciples said, "When will you become revealed to us and when shall we see you?" Jesus said, "When you disrobe without being ashamed and take up your garments and place them under your feet like little children and tread on them, then [you will see] the Son of the Living One, and you will not

(66) J. M. Robinson, "Jesus from Easter to Valentinus (or to the Apostles' Creed)," Journal of Biblical Studies, 101 (1982), pp. 5-37.

(67) Ibid., pp. 28-29.

(68) A. D. DE CONICK and J. Fossum, "Stripped Before God: a New Interpretation of Logion 37 in the Gospel of Thomas," VC, 45 (1991), pp. 123150 . 
be afraid." 69 This Logion 37 and some parallel references can help to understand the stages of the ascent of the soul in the Excerpta ex Theodoto A, 27, namely, how the soul is "stripped ( $\gamma v \mu v \eta)$ by the power of him who has knowledge, as if it had become a body of the power, and passes into the spiritual realm ( $\tau \dot{\alpha} \pi v \varepsilon v \mu \alpha \tau \iota \kappa \alpha ́) . "$

A very close parallel can be found in an adduced by De Conick and Fossum Ode 21 from the Odes of Solomon, where, "after having related that he had "stripped off darkness," "put on light," and acquired a new body ("members") without affliction, the Odist says, "And I was lifted up in the light, and I passed before His face. And I was constantly near Him, while praising and confessing Him." The one having stripped off the body and been anointed, thereby acquiring a glorious body, is elevated to heaven and transformed into an angel of the Countenance, $i$. e., one of the angels performing cultic service before God and therefore being allowed to see his face."70 This text can explain the rhetorical question raised in Excerpta ex Theodoto A, 27, namely, "how can there be a correction ( $\kappa \alpha \tau o ́ \varrho \theta \omega \mu \alpha)$ produced by Scripture and apprehension for the soul which has become pure, when it is granted to see God 'face to face'?"

Furthermore, De Conick and Fossum demonstrated that this theme goes back to Paul. "In his discussion about the spiritual body in 2 Cor. 5, 1-10, Paul is seen to be in dialogue on this very issue. He presents the view that in the resurrection believers will be 'putting

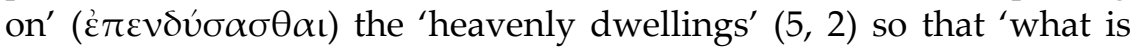
mortal may be swallowed up by life' $(5,4)$. He goes out of his way to make clear to his audience that believers will not be 'unclothed' $(\dot{\varepsilon} \kappa \delta v ́ \sigma \alpha \sigma \theta \alpha \iota)$ of their mortal bodies $(5,4)$. Additionally, Paul states that the reason that the spiritual body is 'put on' ( $\left.\dot{v} \nu v \sigma \alpha \dot{\mu} \mu v v_{0}\right)$ is that, when the mortal body is removed at the time of the resurrection, the person will not be naked before God $(5,3)$. Thus, nakedness to Paul is the condition of having removed the mortal garments of flesh. Apparently, Paul is in a heated debate with a view that during the final resurrection, when the believers ascend to heaven, they will strip off their mortal bodies in order to lay bare spiritual selves before God. Paul instead, contends that the believer will not stand naked

(69) De ConicK and Fossum, "Stripped Before God," p. 123.

(70) Ibid., p. 128. 
before God, but that the mortality will be destroyed by being 'swallowed up' by the heavenly body by God $(5,4) .{ }^{\prime 71}$

\section{B) SCRIPTURAL EXEGESIS AS A LITURGY OF THE LOGOS}

The theme of nakedness and clothing was employed in some early extra-canonical Christian sources, such as the Gospel of Philip and Acts of John, in the context of the exposition of the idea of the comprehension of the Divine Word-Logos through the human words. As G. Luttikhuizen has formulated, "Previous studies have already pointed to the very interesting explanation for this phenomenon in The Gospel according to Philip (NHC II.3). Section 67 (67.9-12) of this Valentinian Gnostic Gospel states: 'Truth did not enter the world naked but in symbols and images. It (the world) will not receive it in any other way.' This fundamental thesis is elaborated in sections 1113. Of special relevance in connection with the manifold names and predicates of the Lord in AJ 98.8-13 is the conclusion of section 12 (54.13-8): 'For our sakes truth produced names in the world because it cannot possibly be known without names. Truth is one. It is (however) manifold for our sakes who are instructed about this one things through many (names) in love'."72

Within the teaching of Marcos Gnosticos, transmitted by Irenaeus, agains the background of which, as it was discussed earlier, the interpretation of the event of the Trasnfiguration by Clement of Alexandria becomes more understandable, "the Logos is also called 'primal Anthropos', or 'Body of Truth', and is composed of thirty letters in four distinct enunciations." 73 Marcus claims also to be shown the "Truth herself," "without a veil" (Adv. hear. 1.14.3). This conception is, probably, implied in an enigmatic sentence from the Excerpta ex Theodoto A, 27, "how can there be a correction ( $\kappa \alpha \tau o ́ \varrho \theta \omega \mu \alpha)$ produced by Scripture and apprehension for the soul which has become pure, when it is granted to see God 'face to face'?"

In what follows I will try to demonstrate that this conception was laid as a foundation for Origen's exegetical theory, developed also by

(71) De ConiCK and Fossum, "Stripped Before God," pp. 130-131.

(72) G. LutTIKHUIZEN, "A Gnostic Reading of the Acts of John," in: The Apocryphal Acts of John, ed. J. N. BREMMER, Kampen, 1995, p. 142.

(73) B. BUCUR, "Matt. 18:10 In Early Christology and Pneumatology: A Contribution to the Study of Matthean Wirkungsgeschichte," NT, 49 (2007), p. 215. 
some other Christian authors. Withing the framework of his exegetical theory Origen employed the theme of the clothes covering the spiritual realm into which a Christian should ascend. As E. A. Dively Lauro has explained, "the Greek term हैv $v \mu \alpha$, translated here as 'outer covering', means garment, or that which covers over something else. The Latin translation speaks of the corpus, or body, of Scripture as the litterae indumentum, or outer covering of the letter. As does $\tilde{\varepsilon} v \delta v \mu \alpha$, indumentum means garment, clothing, or covering. Both terms can refer to the human body in its capacity of covering over all else that makes up the human person, for instance, his soul and spirit. Scripture's body, then, covers over all of its other meanings that are not obvious or external, namely its soul and spirit. Origen refers to Scripture's $\pi v \varepsilon v \mu \alpha \tau \iota \kappa \alpha ́$ or spiritales sensus, both plural forms translated here as 'spiritual truths'. Thus, the somatic sense covers over all spiritual, nonliteral meanings within the biblical text."74

The correlation between the notions of the letters, clothing, and the human body and soul can be found in the Christian writings both preceding and following Origen. In Eclogae Propheticae 24, 2-3 Clement of Alexandria interprets a similar ascent from the material to the spiritual ( $\dot{\alpha} \pi \hat{O} \tau \tilde{\omega} v \dot{v} \lambda \iota \kappa \tilde{\omega} v \dot{\varepsilon} \pi \grave{\imath} \tau \dot{\alpha} \pi v \varepsilon v \mu \alpha \tau \iota \kappa \alpha$ ) while bearing the

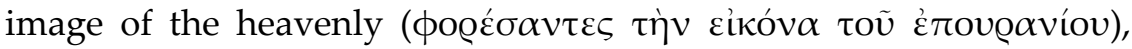
when the Lord marks us with virtues as with character $(\chi \alpha \dot{\alpha} \alpha \gamma \mu \alpha)$ and letters $(\gamma \varrho \alpha ́ \mu \mu \alpha \tau \alpha){ }^{75}$

Similar conception of the human soul stamped by the virtues as by mark or sign, and connected with the image of the clothing ( $\left.\varepsilon^{\prime} v \delta \nu \mu \alpha\right)$ can be found in an anonymous Greek-speaking Syriac writer of the fourth century commonly called Ps. Macarius.

$(30,5)$ Just as in the case of the golden coin, if it does not receive the imprint of the king's image, it does not reach the marketplace nor is it stored up in the royal treasuries, but it is discarded, so also the soul, if it does not have the image of the heavenly Spirit in the ineffable light, namely, Christ, stamped on it, it is not useful for the treasuries above and is cast out by the merchants of the kingdom, the Apostles. For also he who was invited and yet did not wear the wedding garment $(\varepsilon \tilde{v} v \delta \nu \mu \alpha)$ was cast out as a stranger

(74) E. A. Dively Lauro, The Soul and Spirit of Scripture within Origen's Exegesis, Leiden, 2005, p. 54.

(75) Die Griechischen Christlichen Schriftsteller der ersten Jahrhunderte, 17, ed. STÄHLIN, p. 143, 15-19. 
into the alien darkness for not wearing the heavenly image ( $\mu$ i

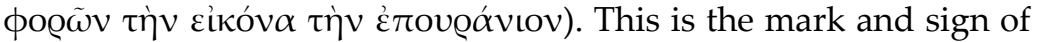

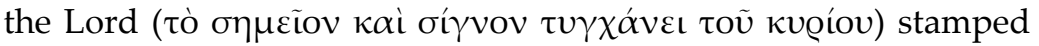

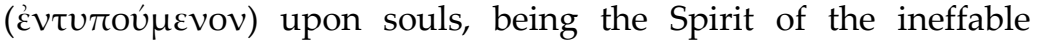
light. ${ }^{76}$

Both authors refer to the First Epistle to the Corinthians 15, where an expression "we shall also bear the image of the heavenly" is put in the following context:

1 Cor. 15: 44-49 “There is a natural body ( $\sigma \omega \dot{\mu} \mu \alpha v \chi$ เкóv), and there is a spiritual body ( $\pi v \varepsilon v \mu \alpha \tau \iota \kappa o ́ v)$. And so it is written, The first man Adam was made a living soul $(\psi v \chi \eta \dot{\eta} v \zeta \tilde{\omega} \sigma \alpha v)$; the last Adam was made a quickening spirit ( $\pi v \varepsilon \tilde{v} \mu \alpha \zeta \omega$ o $\pi$ oเoṽv). Howbeit that was not first which is spiritual ( $\pi v \varepsilon v \mu \alpha \tau$ cóv), but that which is natural ( $\psi v \chi \iota \kappa o ́ v)$; and afterward that which is spiritual.

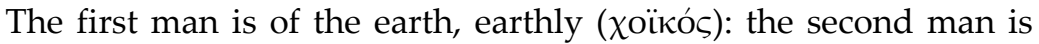
the Lord from heaven. As is the earthly, such are they also that are earthly: and as is the heavenly, such are they also that are heavenly. And as we have borne the image of the earthly, we shall also

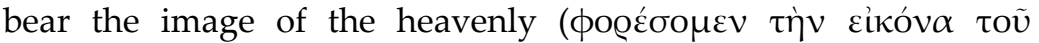

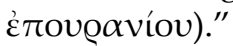

In this passage the triple structure of the human being is described, to which refers as well Ps.-Macarius in the same Letter where he described the soul stamped by sign and seal of virtues.

(30. 3) ... as many as believe the Lord and come to be deemed worthy of receiving this birth, they bring joy and great happiness in Heaven to the parents that gave them birth. And all the angels and holy powers rejoice over a person who is born of the Spirit and has become spirit. For this body is a likeness to the soul and the soul is an image of the Spirit. ${ }^{77}$

This triple structure of the human being was described in detail by W. Williams: "Harry Allen Wolfson discerned three stages of existence in Philo's Logos. David Runia prefers to speak of three "levels" of operation. In both systems, there is a transcendent Logos, nearly indistinguishable from God; an immanent Logos, "incarnate in" or "permeating through" the material cosmos; and an intermediate

(76) Pseudo-Macarius, The Fifty Spiritual Homilies and the Great Letter, tr. G. A. MALONEY, New York, 1992, p. 190-191.

(77) Ibid., p. 190. 
Logos bridging the two. The latter is the demiurge of the material cosmos. A close reading of Philo allows us to associate these three stages/levels with the three Adams found in various exegetical traditions of Gen. 1-2, particularly in those texts termed 'Gnostic.' According to the Nag Hammadi tractate On the Origin of the World 117:29ff, "the first Adam is spirit-endowed (pneumaticos), and appeared on the first day. The second Adam is soul-endowed (psychikos), and appeared on the sixth day, which is called Aphrodite. The third Adam is a creature of the earth (choicos), that is, the man of law, and he appeared on the eighth day" These three Adams are not individual men; they are stages in the somatic (d)evolution of Man. This somatic tripartition, common in Gnostic texts, is based on a popular reading of Genesis 1-2. The pneumaticos or spiritual first Adam, born on the first day, is associated both with the Spirit of God that hovered over the pre-mundane waters (Gen 1:2) and, more commonly, the light of Gen. 1:3. The latter reading is based on a pun on the Greek word phōs, used in the LXX translation of Gen. 1:3 meaning both light" and "man." Thus, the product of God's command, "Let there be light (phōs)," was a divine Light-Man, as anthropos enveloped within and consisting of light."78

The triple structure of pneumatic, psychic and somatic Man can lie behind the three levels of the exegesis of the Scripture elaborated by Origen who in De principiis IV, 4 (11) openly compared his three levels with man consisting of body, soul, and spirit, and united this comparison with the quotation from Hebr 10:1, which was important for the understading the Excerpta ex Theodoto A, 27,1-6:

Just as man consists of body, soul and spirit, so in the same way does the scripture, which has been prepared by God to be given for man's salvation. ${ }^{79}$

The conception of the Scripture as Man was preserved in a modified form in the seventh-century Byzantine author Maximus the Confessor.

...the whole Scripture likewise stands for man, with the Old Testament as the body, the New as the soul, spirit, and mind. But also the literal narrative of all Scripture, of both the Old Testament and

(78) WILLIAMS, THE SHADOW OF GOD.

(79) Origen, On First Principles: Being Koetschau's Text of the De Principiis, tr. G. W. BUTTERWORTH, Gloucester, Mass., 1973, p. 276. 
the New, is the body; and its soul is the meaning of the words and the objective at which the meaning is aimed. ${ }^{80}$

As P. M. Blowers has remarked, Maximus the Confessor inherited the conception of Origen of the incarnation of the Logos into the words of the Scripture. ${ }^{81}$ Moreover, in the Quaestiones as Thalassium 62 St. Maximus writes:

(The Logos) who formed himself ( $\dot{\varepsilon} \alpha v \tau$ òv $\delta \iota \alpha \pi \lambda \alpha ́ \alpha \alpha \varsigma)$ mystically

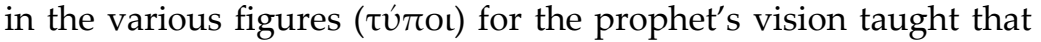
he was in truth about to submit voluntarily, and by nature, to our

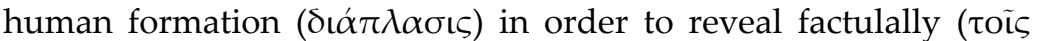
$\pi \varrho \alpha ́ \gamma \mu \alpha \sigma \iota)$ the present truth $(\pi \alpha \varrho 0 \tilde{\sigma} \sigma \alpha \dot{\alpha} \lambda \eta \dot{\theta \varepsilon \iota} \alpha)$ predicted through the figures. ${ }^{82}$

The terminology of St. Maximus resembles again the sentence from the Excerpta ex Theodoto A, 27,1-6 (Thus, having transcended the angelic teaching and the Name taught in Scripture, it comes to the

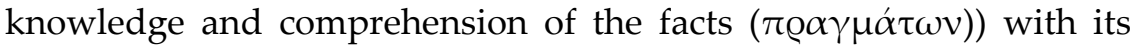
implication of Hebr 10:1 "For the law having a shadow of good things

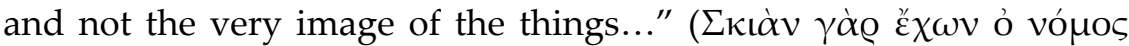

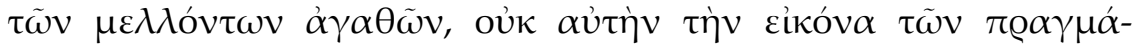
$\tau \omega \nu . .$.$) . As it was discussed earlier, the notions of the "image" and$ "shadow" are employed by Philo, for whom the "...aerial/psychic body signified by the blue robe is in some way related to... designation of the demiurgic Logos as both God's Image and 'Shadow' (Leg. III.96)." 83 Philo identifies the Logos with Bezalel ('In the Shadow of God'), chief craftsman of the Tabernacle and its works according to Exod. 31:2ff." 84 W. Williams attempted to demonstrate that behind Philo's exegesis lies a Scriptural priestly interpretation of the Tabernacle as Man ${ }^{85}$ and also pointed out that "As is well-known, Philo's

(80) The Church, the Liturgy and Soul of Man. The Mystagigia of St. Maximus the Confessor, tr., with historical note and comm. by Dom Julian STEAD, O.S.B., Still River, Mass., 1982, pp. 82-83.

(81) P. M. Blowers, Exegesis and Spiritual Pedagogy in Maximus the Confessor: An Investigation of the Quastiones ad Thalassium, Notre Dame, 1991, pp. 119-120; 168, n. 115.

(82) Ibid., p. 121.

(83) WILLIAMS, THE SHADOW OF GOD.

(84) Ibid.

(85) "James Barr and Tryggve N. D. Mettinger have observed that both Adam and the Tabernacle (and Temple; cf. 1 Ch. 28:11f, 18f), and only these 
Logos is the deity in his accessible aspect; he is the Image of God through which the latter may be seen; he is demiurgic - the instrument (organon) through which the universe was created and ordered. And he is anthropomorphic; God's man (anthropos theou) and 'the Man after His Image'." ${ }^{86}$

M. Barker made a comparison between the designation of Logos by the Shadow, made by Philo, with the conception of the shadow in Nag Hammadi text The Nature of the Archons (CG. II.4), where "the angel... explained the creative process: 'A veil exists between the world above and the realms that are below; and a shadow came into being beneath the veil; and that shadow became matter; and that shadow was projected apart. And what she (Sophia) had created became a product in the Matter, like and abortive foetus.' (Here there is the divine being passing through the veil and taking material form). Philo had called the Logos the Shadow: 'God's shadow is his Logos, which he made use of like an instrument and so made the world' (Allegorical Interpretation, III.96)." 87

Similar understanding of the creatured world as the shadow can be found in a Syriac text of an anonymous author (fourth-fifth century), The Book of Steps, Memra 21.

They (Adam and Eve) exchanged heaven for earth and left heaven and loved the earth. They exchanged that thing that does not pass away and is imperishable and acquired what passed away and is perishable. They exchanged the perfect original for the shadow, as

two according to $\mathrm{P}$, are made according to a heavenly prototype (Urbild; şelem/tabnit). "The P source had two great events in which something was made in an express analogy: firstly, man himself, created in an image of God, and, secondly, the tabernacle, built by men after a pattern revealed by God." As Mettinger notes, this can hardly be accidental. He goes on to proffer the thesis that the heavenly prototype in Genesis (the şelem) refers to the heavenly beings who carry out worship in the heavenly temple. It seems to us that this "surprising analogy between man and the Tabernacle" is more easily explainable by the clear pattern we have discerned in P's use of this intertextuality. The Adam/Aaron: Tabernacle homology strongly suggest that $\mathrm{P}$ intends to present the first man as the first divine sanctuary" (WILLIAMS, THE SHADOW OF GOD).

(86) WILLIAMS, THE SHADOW OF GOD.

(87) M. BARKER, The Gate of Heaven. The History and Symbolism of the Temple in Jerusalem, London, 1991, pp. 119-120. 
the apostle said, "Everything visible is a shadow of that thing that is invisible and does not pass away." 88

They decided to descend from the heavenly Paradise that is the perfect original, and lived on the earth that is the shadow of what is invisible to the eyes of the flesh; that is, the shadow of that heavenly Paradise. Adam descended and stood in the earthly paradise that is the shadow of heaven. ${ }^{89}$

Irenaeus in the Demonstration of the Apostolic Preaching designated the Body of Christ as the shadow, probably, in this way expressing his conformity to the teaching exposed in the Hebrews Epistle, according to which the Body of Christ is associated with the veil of the Temple.

71. And in another place Jeremiah says: The Spirit of our face, the Lord Christ; (III, xi. 2): and how He was taken in their snares, of whom we said, Under his shadow we shall live among the Gentiles. That, being (the) Spirit of God, Christ was to become a suffering man the Scripture declares; and is, as it were, amazed and astonished at His sufferings, that in such manner He was to endure sufferings, under whose shadow we said that we should live. And by shadow he means His body. For just as a shadow is made by a body, so also Christ's body was made by His Spirit. But, further, the humiliation and contemptibility of His body he indicates by the shadow. For, as the shadow of bodies standing upright is upon the ground and is trodden upon, so also the body of Christ fell upon the ground by His sufferings and was trodden on indeed. And he named Christ's body a shadow, because the Spirit overshadowed it, as it were, with glory and covered it. [The words appear to mean literally: "the Spirit becoming as it were a shadow with glory and covering it (or him)."].90

The idea of the illumination of the shadowy material substance by the glory of Spirit, expressed in the last sentence, resembles a similar technical explation of the illumination of the matter by the soul made by Plotinus I, 1 [53] 12, 25-28: "If the inclination is an illumination directed to what is below it is not a sin, just as casting a shadow is not

(88) The Book of Steps: The Syriac Liber Graduum, tr. with an Introduction and notes by R. KiTCHEN and M. PARMENTIER, Kalamazoo, 2004, p. 235.

(89) Ibid., p. 241.

(90) Translation from the Armenian in St. Irenaeus, The Demonstration of the Apostolic Preaching, tr. from the Armenian with introduction and notes by J. ARmitage Robinson, London, New York, 1920, pp. 131-132. 
a sin; what is illuminated is responsible, for if it did not exist the soul would have nowhere to illuminate." 91

On the other hand, Ps. Macarius indentified the Logos as 'Shad$\mathrm{ow}^{\prime}$, similar to that made by Philo, with reference to the truth $(\alpha \lambda \eta \dot{\eta} \varepsilon\llcorner\alpha)$, in the context of the meaning of the spoken or written divine words, as will be later employed by Maximus the Confessor.

(30.1) Those who hear the word should give witness to the working of the Word in their souls. The word of God is not an idle word, but it has its own work upon the soul. For this reason it is called a "work" so that the work may be found in those who hear it. May the Lord, therefore, grant the work of truth in the hearers so that the Word may be found fruitful in us. For just as the shadow ( $\sigma \kappa \iota \dot{\alpha})$ precedes the body $(\sigma \tilde{\omega} \mu \alpha)$, but reveals it, so also, while

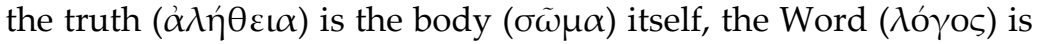
like a shadow of the truth of Christ. Thus the Word precedes the truth..$^{92}$

J. Daniélou, with his critical approach to Origen's theory of the three senses, has remarked that this Church Father for practical exegetical purposes employed the approach to Scripture constituting "the three levels of shadow, image... and reality." 93 In any way, Origen added to the threefold vertical structure the horizontal dimension of the juxtaposition of the Shadow, referring to the Old Testament, and the Image, referring to the risen Christ, ${ }^{94}$ who serves as a High Priest

(91) Armstrong's translation; LCL 440; Plotinus, Porphyry on Plotinus. Ennead I, Cambridge, Mass., London, 1995, p. 119.

(92) Pseudo-Macarius, The Fifty Spiritual Homilies and the Great Letter, tr. MALONEY, p. 189.

(93) J. DANIÉLOU, Gospel Message and Hellenistic Culture, tr. J. A. BAKER, Philadelphia, 1973, p. 288.

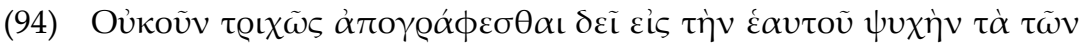

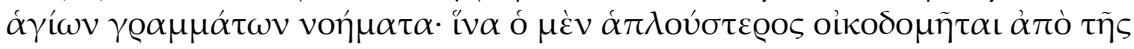

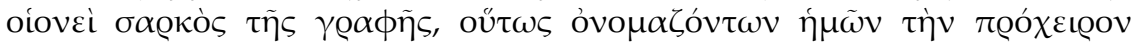

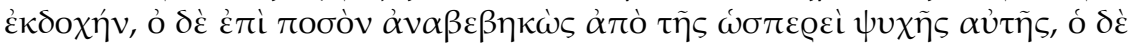

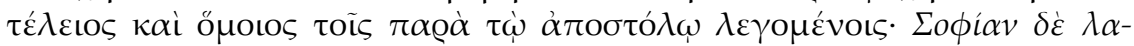

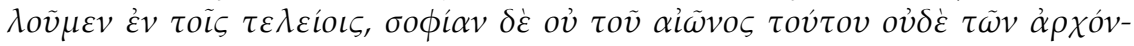

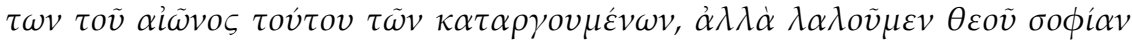

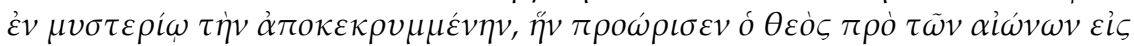

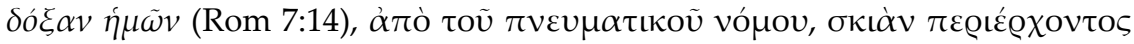

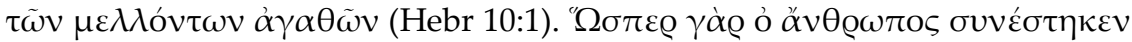

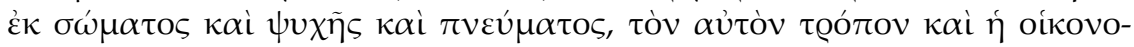


uplifting the Christians from the body towards the spirit of Scripture, which is associated with the Man-Tabernacle. As it was analysed by E. A. Dively Lauro, in his Homily on the Numbers 9 (treating Num. 17:1-5 and 8) Origen interpreted the fruit of the Aaron's rod sprouting forth almonds as the "pontifical fruit (pontificalis fructus)," meaning that which comes from the high priest. The High Priest is identified in another passage of this Homily as Christ, while the almond is interpreted as a figure of Scripture's three meanings by relating them to each of the part of the almond, the husk, shell and centre. ${ }^{95}$

This conception of the High Priestly Logos can lie behind the ex-

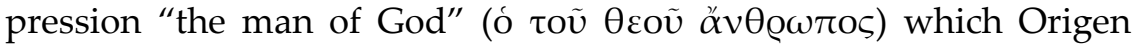
uses in the passage from the Contra Celsum, where he criticizes the anthropomorphic conceptions of God.

(VII, 38) Since we affirm that the God of the universe is mind, or that He transcends mind and being, and is simple and invisible and incorporeal, we would maintain that God is not comprehended by any being other than him made in the image of that mind. To quote the words of Paul, we comprehend Him "through glass and in a riddle, but then face to face" (I Cor. 13: 12). And if I say "face," let no one base upon the word a false charge against the meaning indicated by this word. Let him learn from the words "with unveiled face reflecting as in a glass the glory of the Lord and being transformed into the same image from glory to glory" (2 Cor. 3:18), that it is not a sensible face to which these words refer, but one which is understood by allegorical interpretation, just as eyes, and ears, and all the other things which, as we have shown above, bear the same name as parts of the body.

A man, that is a soul using a body, the soul being called 'the inner man', and a soul also, would never make the reply which Celsus has written, but that which the man of God (ó tov $\theta \varepsilon \circ \tilde{v}$ $\alpha \ddot{v} \theta 0 \omega \pi \mathrm{\rho})$ himself teaches. And no Christian would speak an utterance of the flesh, since he has learnt to mortify by the Spirit the deeds of the body and to bear about always the dying of Jesus, and has the command: "Mortify your members that are upon earth" (Col. 3:5). He knows what is meant by the saying: "My Spirit shall not abide among these men for ever because they are flesh"

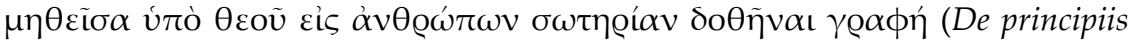
IV, 4 (11), 111-125; SC, 312 (1984), p. 310-312).

(95) E. A. Dively LaURO, The Soul and Spirit of Scripture within Origen's Exegesis, Leiden, 2005, pp. 109-118. 
(Gen. 6:3). He is aware also that "those who are in the flesh cannot please God" (Rom. 8:8), and on this account does all in his power in order that he may be in the flesh no longer, but in the spirit alone. ${ }^{96}$

Thus, according to Origen, a Christian believer should not comprehend the scriptural anthropomorphisms literally. Nevertheless, parts of the Divine Body are implanted in the texture of the Scripture, which is identified with Man. Therefore, quite in accordance with this conception, Maximus the Confessor in his interpretation of the Transfiguration in Quaestiones et dubia 191 uses such expression as "face of

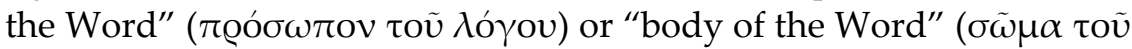
$\lambda o ́ \gamma o v)$, by which he seems to refer to the conception of the anthropomorphic Logos, evoking similar conception in Philo. St. Maximus remarked that since in the Scripture there is a mention of the garment (íádıov), he feels obliged to mention the body, by which one would expect the identification of the body and the garment. Nevertheless, Maximus says that the body of the Word is the substance of the vir-

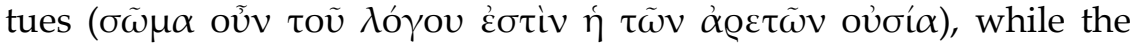
garments (i $\mu \alpha \dot{\alpha} \tau \alpha)$ of the Word are the sayings of the Scripture ( $\tau \dot{\alpha}$ $\tau \tilde{\eta} \varsigma \gamma \varrho \alpha \phi \tilde{\eta} \varsigma \varrho \emptyset \eta \mu \tau \tau)$ and the creatured universe. This sequence, as it seems, presupposes a conception of the gradual (de)volution of the luminous Logos-Anthropos. The garments of the Logos, probably, echo the Jewish esoteric conception of haluq, a splended white garment, into which the Divine Body is enrobed, and upon the inside and outside of which the tetragrammaton is etched. St. Maximus further explains that this garment looks white by those who have stripped off the letter of the Scripture from the inherent in it thickness

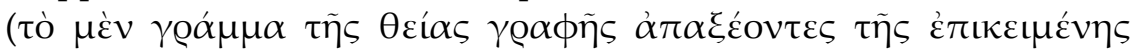

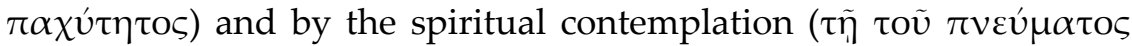

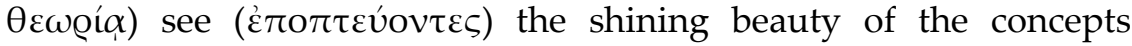
$(v o \eta \mu \alpha ́ \alpha \omega v){ }^{97}$

This conception correlates with the sentence from the discussed previously passage in the Excerpta ex Theodoto: "Now the soul, stripped by the power of him who has knowledge, as if it had become a body of the power ( $\sigma \omega \mu \alpha \tau \tilde{\tau} \varsigma \delta v v \alpha \dot{\mu} \mu \omega \varsigma)$, passes into the spiritual realm." In this way, an expression "body of the Word" used by Max-

\footnotetext{
426.

(96) Origen, Contra Celsum, tr. H. CHADwICK, Cambridge, 1980, pp. 425-

(97) Quaestiones et dubia, 191 (CCSG, 10), p. 134, 47-63.
} 
imus the Confessor, probably, can shed light on the meaning of expressions "body of the power," or "body of the Lord" from the Excerpta ex Theodoto. According to St. Maximus, the "body of the Word" is interpreted as the "substance of the virtues," and in Eclogae Propheticae 24, 2-3 Clement of Alexandria interprets an ascent from the ma-

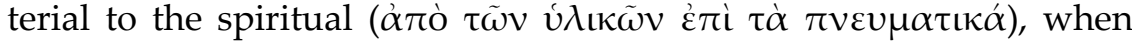
the Lord marks us with virtues as with character $(\chi \alpha \dot{\rho} \propto \alpha \gamma \mu \alpha)$ and letters $(\gamma \varrho \alpha \mu \mu \alpha \tau \alpha)$. Therefore, in the interpretation of Maximus the Confessor, the event of the Transfiguration, following the interpretation of Clement and Origen, is interpreted as the incarnation of the Logos in the letters of Scripture, and the spiritual edification of Christian souls leads to their transformation into spiritual bodies, which can be represented by the celestial Letters covering the Body of Truth.

\section{C) THE INCARNATION OF CHRIST INTO THE LETTERS AND IMAGES OF THE SCRIPTURE IN THE HERMENEUTICAL THEORY OF AUGUSTINE}

As it was discussed earlier, M. Barker has demonstrated that the vestments of the High Priest corresponded to the veil of the Temple pointing out that "the veil was the boundary between earth and heaven. Josephus and Philo agree that the four different colours from which it was woven represented the four elements from which the world was created: earth, air, fire and water. The scarlet thread represented fire, the blue was air, the purple was the sea, i. e. water, and the white linen represented the earth in which the flax had grown (War 5.212-213). In other words, the veil represented matter. The high priest wore a vestment woven from the same four colours and this is why the Book of Wisdom says that Aaron's robe represented the whole world (Wisd. 18.24; also Philo, Laws 1.84; Flight 110)." 98 On the other hand, W. Williams has indicated on the fact that "According to the rabbinic Body: Tabernacle homology, the goat-hair coverings of the Tabernacle (v. Exod. 26:7-11) correspond to the skin of Adam. These also corresponded to the sapphiric blue sky... the first of seven heavens." 99

Origen and Maximus the Confessor in their exegetical theories employed the symbolism of the vestments of the Logos applying it to

(98) BARKER, The Great High Priest, p. 190.

(99) WILLIAMS, THE SHADOW OF GOD. 
the letters of the Scripture. Similarly, Augustine in Confessions 13 employed the symbolism of the coverings of the Tabernacle corresponding to the skin of Adam and the first heaven.

xv (16) Who but you, O God, has made for us a solid firmament of authority over us in your divine scripture? For "the heaven will fold up like a book" (Isa. 34: 4), and now "like a skin it is stretched out" above us (Ps. 103: 2). Your divine scripture has more sublime authority since the death of the mortal authors through whom you provided it for us. You know, Lord, you know how you clothed human beings with skins when by sin they became mortal (Gen. 3:21). So you have stretched out the firmament of your book "like a skin," that is your words which are not mutually discordant, and which you have placed over us by the ministry of mortal men. Indeed, by the very fact of their death the solid authority of your utterances published by them is in a sublime way "stretched out" over everything inferior. ${ }^{100}$

Therefore, as I will try to demonstrate in what follows, although the theory of the Scriptural exegesis elaborated by Augustine seems to be based on certain elements of Stoic and Neoplatonic linguistic theories, nevertheless, one can discern in the Augustinian theory also traces of the Jewish-Christian mysticism of letters, which he transmitted to the Latin West.

According to Augustine, with the help of the arts one can understand the figurative signs of the Scripture (Book two, XXVI-XXXVI), as with the help of the knowledge of the languages one can understand its literal signs (Book two, XI-XVI). The signs are divided into natural and conventional. The conventional signs are the means of expression of the thought. This idea of Augustine corresponds to his theory of the Incarnation as the thought expressed in words. For Augustine, some selected things are the signs, by which God communicates with men. On the other hand, these things-sings become the symbols of the body of Christ, while the thought expressed by this speech is the divine nature of Christ.

(Book 1, 26). And what was the manner of his coming, if not this: "The word was made flesh and lived among us." (Jn. 1:14)? When we speak, the word which we hold in our mind becomes a sound in order that what we have in our mind may pass through ears of flesh into the listener's mind: this is called speech. Our thought,

(100) Augustine, Confessions, tr. H. CHADWICK, Oxford, 1991, p. 282. 
however, is not converted into the same sound, but remains intact in its own home, suffering no diminution from its change as it takes on the form of a word in order to make its way into the ears. In the same way the word of God suffered no change although it became flesh in order to live in us. ${ }^{101}$

This thought of Augustine echoes Origen's conception of the Incarnation of Christ through the Scripture. ${ }^{102}$ On the other hand, the Augustine's sentence "But our thought is not transformed into sounds; it remains entire in itself and assumes the form of words by means of which it may reach the ears without suffering any determination in itself" almost repeats a phrase from the Plotinian passage about the logos unfolding the contents of the intellectual act: "The intellectual act is without parts and has not, so to speak, come out into the open,

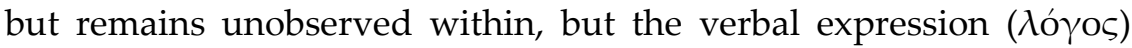
unfolds its content" which then "brings it out of the intellectual act into the image-making power, and so shows the intellectual act as if in a mirror, and this is how there is apprehension and persistence and memory of it. (IV , 3 [27] 30, 7-11)"103 In another passage Plotinus, as it seems, juxtaposes to the "intellectual act without parts" the "spoken

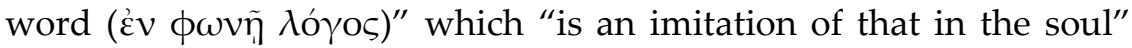
and which is "broken up into parts as compared with the soul" (I, 2 [19] 3, 26-31). ${ }^{104}$

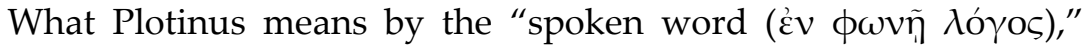
"broken up into parts" ( $\mu \varepsilon \mu \varepsilon \rho เ \sigma \mu \varepsilon ́ v o \varsigma)$ seems to be that of which

(101) Augustine, De Doctrina Christiana, ed. and tr. R. P. H. GREEN, Oxford, 1995, pp. 23-25.

(102) “Comme la parole, intangible en soi, se fixe dans l'écriture, ainsi le Verbe divin, d'intangible qu'il était, peut être vu, touché et lu dans les

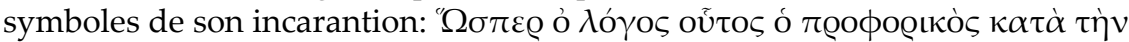

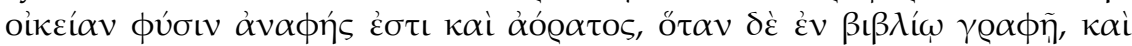

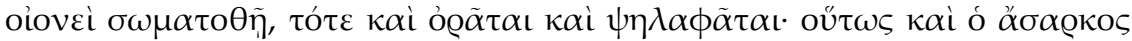

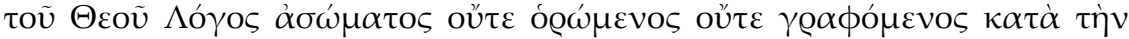

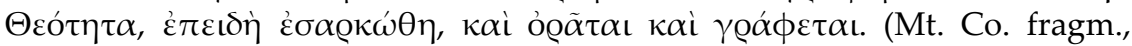
M. 17, 289A)" (H. vON BALTHASAR, "Le mysterion d'Origène," Recherches de Sciences Religieuse, 27 (1936), pp. 539-540)

(103) A. H. Armstrong's translation. Cf. Plotinus, Ennead IV with an English translation by A. H. ARMSTRONG, Cambridge, MA, London, 1984, pp. 129-131.

(104) A. H. Armstrong's translation. Cf. Plotinus, Ennead I, tr. ARMSTRONG, p. 137. 
"the Stoics were the main inventors," namely, "of what was to become the standard parts of speech system. They were the first to distinguish consistently between phonetic elements (the stoicheia tes lexeos, 'elements of the utterance') and what we would now call elements of the grammatical construction, and they refer to the latter specifically as 'parts' (mere) or - the term is also used by them and sporadically later - as 'elements' (stoicheia) of a meaningful utterance or sentence (logos)." 105 For Plotinus this logos, as an image of the logos in the soul, is inferior in comparison with that about which, probably, Plotinus speaks in a previously referred to passage that it shows the intellectual act in the image-making power as if in a mirror; even more this spoken logos is inferior to the intellectual act, which is without parts. As to the intermediary element in the Plotinian construction, namely, the logos in the soul, it can be as well explained with the reference to the Stoic grammatical theory, in which "the parts of a logos are... divisions of a material signifier (semainon, 'signifying') whose signification (semainomenon, 'that being signified') is an immaterial entity which formed a separate object of study."106 Probably, this immaterial entity can correspond to the Plotinian "logos in the soul."

Augustine was well versed in the Stoic grammatical theory. ${ }^{107}$ In addition, he considered the work of an exegete as comparable to that of a teacher of grammar (On Christian Doctrine, Prologue, 9). The task of a grammarian in Alexandrian school was the reading, exposition, correction and judgement of the literary works of the great ancient poets and prose writers, and partly this understanding of the task of grammar and grammarian was transferred into the Latin literary culture by Quintilian and Cicero. ${ }^{108}$ However, according to Augustine, the work of an exegete can be compared with this sort of work, similar to an Alexandrian grammarian, only on the level of studying the literary meaning of the Scripture. Augustine elaborated the theory of the "exegetical grammar" with its own rules, as it was noted by

(105) History of Linguistics, vol. II, Classical and Medieval Linguistics, ed. G. LEPSCHY, London, New York, 1994, pp. 34-35.

(106) Ibid., p. 33.

(107) Cf. J. RIST, Augustine: Ancient Thought Baptised, Cambridge, 1994, pp. 28-30; A. A. LONG, "Stoic Linguistics, Plato's Cratilus, and Augustine's De dialectica," in: Language and Learning: Philosophy of Language in the Hellenistic Age, ed. D. Frede, B. INWOOD, Cambridge, 2005, pp. 36-55.

(108) History of Linguistics, vol. II, pp. 2, 54. 
B. Bureau. "Bien évidemment, il s'agit là d'un schema et l'ambivalence du mot littera qui s'applique aux deux systèmes de lecture témoigne de la nécessaire interpénétration de l'un et de l'autre. Mais l'idée est absolument claire. La Bible superpose à la langue courante, quelle qu'elle soit d'ailleurs, une langue mystique, gérée par sa grammaire propre. La tâche de l'exégète est alors parente de celle du grammarien: expliquer (exponere, tractare) la syntaxe propre $\mathrm{du}$ langage mystique pour permettre au lecteur de le lire avec autant de facilité que le langage courante." 109 Probably, this ambivalence of the word littera and the implication that in the Scripture there are two kinds of grammar can reflect the Plotinian distinction between the spoken logos (which, in Augustine, constituting the "word of God," is not inferior, but to a certain extent symmetrical to the Wordthought) and the logos in the soul, to which Plotinus seems to ascribe the role of unfolding the contents of the intellectual act into its imagemaking power, which is connected with the memory.

In Augustine, according to J. Rist, "...the contents of our memory are of two formally distinct sorts: images of particular objects, experiences and events in time and historical sequence - these are our immediate concern in considering questions of scepticism; and 'things themselves' recognized by the mind, namely the objects of mathematics, logic and above all metaphysics, that is the Platonic Forms which invariably by 'nature' or, in accordance with our learning, by acquisition, constitute the furniture of the mind. Such 'ideas', as Augustine had learned from Plotinus, are both 'in' the mind of God and somehow also present to what Plotinus calls our human 'upper soul'." 110 In Plotinus, the images, connected with the memory, appear as a result of the unfoldment of the contents of an intellectual act, by the logos in the soul, which is, probably, juxtaposed to the spoken logos. The liberal arts, then, in Augustine, can be connected with the Plotinian "logos in the soul"(or Reason in Augustine's Soliloquies), and then they are connected with the realm of the soul, like in Iamblichus, Proclus, and Marcianus Capella (see Excursus). In this way, the Plotinian scheme: intellectual act - logos in the soul - image-making power - spoken logos can be transformed in Augustine

(109) B. BurEAU, “Littera: 'sens' et 'signification' chez Ambroise, Augustin et Cassiodore," in: Conceptions latines $d u$ sens et de la signification. Colloque du Centre Alfred Ernout, ed. M. BARATIN et C. Moussy, Paris, 1999, p. 223.

(110) J. Rist, Augustine: Ancient Thought Baptised, Cambridge, 1994, p. 76. 
into: thought - liberal arts - signs of the Scripture (corresponding to Plotinian "image-making power") - words of the Scripture. All this is inserted into the general scheme: the Word of God - soul body of Christ, by which Augustine developed Origen's Christological implications of the theory of Scriptural exegesis.

On the other hand, in the exegetical theory of Augustine an important role is assigned to the virtues, and in some passages it seems even that the virtues serve as an alternative way of approaching to and acquiring the knowledge of God. Thus, according to Augustine, he who is

strengthened by faith, hope, and love, and who steadfastly holds on to them, has no need of the scriptures except to instruct others. That is why many people, relying on these three things, actually live in solitude without any texts of the scriptures. They are, I think, a fulfilment of the saying "If there are prophesies, they will lose their meaning; if there are tongues, they will cease; if these is knowledge that too will lose its meaning." (1 Cor. 13:8). By these devices (so to speak) such an edifice of faith, hope, and love has been built in them that they do not seek what is imperfect (1 Cor. 13:10), for they hold what is perfect - perfect, that is, as far as anything can be in this life; for in comparison with the life to come the life of no righteous or holy man in this world is perfect. ${ }^{111}$

However, close reading of Augustinian texts seems to allow to discern the idea of an edifying of Christian souls trained in virtues correlating with a corresponding idea of Incarnation and Crucifixion of Christ in the Letters of the Scripture. The quoted passage, as it seems, echoes a Paulinian text, 2 Cor 3:2-3: "Ye are our epistle written in our heart, known and read of all men; for as much as ye are manifestly declared to be the epistle of Christ manifested by us, written not in ink, but with the Spirit of the Living God; not in tables of stone, but in the fleshly tables of the heart," about which J. A. Fitzmyer observed that the "...association begins with the idea of something written, something having letters; this is no longer 'letter' in the sense of epistole, but 'letter' as gramma(ta), i. e. letters of the alphabet with which one writes a document." 112 The same scholar discovered that

(111) Augustine, De Doctrina Christiana, ed. and tr. R. P. H. GREEN, Oxford, 1995, p. 53.

(112) J. A. FITZMYER, According to Paul: Studies in the Theology of the Apostle, New York, 1993, pp. 69-70. 
Paul here develops his version of the midrashic interpretation of Exod 43:27-35, which has its parallel in the Qumran literature.

This Paulinian text seems to be paraphrased by the author of a Nag Hammadi treatise the Gospel of Truth:

After all these, there came the little children also, those to whom the knowledge of the Father belongs. Having been strengthened, they learned about the impressions of the Father. They knew, they were known; they were glorified, they glorified. There was manifested in their heart the living book of the living - the one written in the thought and the mind [of the] Father, which, from before the foundation of the totality, was within his incomprehensibility that (book) which no one was able to take, since it remains for the one who will take it to be slain. ${ }^{113}$

Corresponding motive of the Father's face is present also in another passage from the Gospel of Truth, where one can find a clarification of the way of reaching the knowledge of the Father:

For the place to which they send their thought, that place is their root, is what takes them up in all the heights to the Father. They possess his head, which is rest for them, and they are supported, approaching him, as though to say that they have participated in his face by means of kisses. ${ }^{114}$

The theme expressed by the last sentence, as it seems, can imply a reference to Mt 18:10 “Take heed that ye despise not one of these little ones; for I say unto you, that in heaven their angels do always behold the face of my Father which is in heaven." In his article devoted to the interpretations of this Scriptural passage by early Christian authors B. Bucur ${ }^{115}$ has demonstrated that this theme can be referred to in the teaching of Marcos Gnosticos, as it is exposed by Irenaeus in $A d v$. Haer. I. 13-14, where Marcus, as it seems, calls the angels-twins of the Christians by the term "greatnesses." 116 They are, probably, identical with the angels who "continually behold the face of the Father," the forms of the letters, whom E. Wolfson also connects with the same

(113) Tr. of H. W. AttRIDGe and G. W. MAcRAE, in: The Nag Hammadi Library in English, ed. J. M. ROBONSON, Leiden, 1996, p. 41.

(114) Tr. of AtTRIDGE and MACRAE, in: The Nag Hammadi Library, p. 60.

(115) B. BUCUR, "Matt. 18:10 in Early Christology and Pneumatology: a Contribution to the Study of Matthean Wirkungsgeschichte," NT, 49 (2007), pp. 209-231.

(116) Ibid., pp. 214-216. 
passage of Mt 18:10, indicating of the connection of this conception with the Jewish mystical tradition, which is traceable as well in the Gospel of Truth. ${ }^{117}$ In this case, probably, those, about whom it is said in the Gospel of Truth that they participated in the Father's face, also represent the letters, if to take into consideration the following passage:

It was a great wonder that they were in the Father, not knowing him and (that) they were able to come forth by themselves, since they were unable to comprehend him and to know him in whom they were. For if his will had not thus emerged from him, - for he revealed it in view of a knowledge in which all its emanations concur. This is the knowledge of the living book which he revealed to the aeons, at the end, as [his letters], revealing how they are not vowels nor are they consonants, so that one might read them and think of something foolish, but they are letters of the truth, which they alone speak who know them. Each letter is a complete [thought] like a perfect book, since they are letters written by the Unity, the Father having writen them for the aeons, in order that by means of his letters they should know the Father. ${ }^{118}$

Very similar imagery is used by Augustine in Confessions 13:15

Let the people above the heavens, your angels, praise you. They 'ever see your face' (Matt. 18:10) and there, without syllables requiring time to pronounce, they read what your eternal will intends. They read, they choose, they love. They ever read, and what they read never passes away.By choosing and loving they read the immutability of your design. Their codex is never closed, nor is their book ever folded shut. For you are yourself are a book to them and you are "for eternity" (Ps. 47:15). ${ }^{119}$

On the other hand, an author of the Gospel of Truth has formulated the event and the significance of the Crucufixion of Christ in the following way: "He put on that book, he was nailed to a tree, he published the edict of the Father on the cross." ${ }^{120}$ In the work On Christian Doc-

(117) E. WOLFSON, "Inscribed in the Book of the Living: Gospel of Truth and Jewish Christology," Journal of the Study of Judaism, 38 (2007), pp. 269271.

(118) Tr. of AtTRIDGE and MACRAE, in: The Nag Hammadi Library, p. 43.

(119) Augustine, Confessions, tr. by H. CHADWICK, Oxford, 1991, p. 283.

(120) Tr. of AtTRIDGE and MACRAE, in: The Nag Hammadi Library, p. 42. 
trine the symbolism of the cross is implanted into the hermeneutical theory of Augustine.

(Book II, 148-149) As students of the divine scriptures, equipped in this way, begin to approach the task of studying them in detail, they must ponder incessantly this phrase of the apostle Paul: "knowledge puffs up, but love builds up" (1 Cor. 8:1). In this way, even if they leave Egypt well provided for, they realize that without first observing the passover they cannot be saved. Now "Christ our Passover has been sacrificed" (1 Cor. 5:7); the sacrifice of Christ teaches us nothing more clearly than what he himself calls out, as if to those whom he sees suffering in Egypt under Pharaoh: "Come unto me, you who labour and are heavy laden, and I will refresh you. Take my yoke upon you and learn from me, for I am gentle and lowly in heart, and you will find rest for your souls. My yoke is a soft one, and my burden light." (Mt 11:28-30). Who are these but the gentle and lowly in heart, people not puffed up by knowledge but built up by love? Remember those who celebrated the Passover in days gone by, in its unreal and shadow form; when the command was given to mark their gateposts with the blood of a lamb, they were also sprinkled with hyssop. This is a lowly and gentle plant, but nothing is stronger or more penetrating than its roots, so that 'rooted and grounded in love' we may be able "to comprehend with all the saints what is the breadth and length and height and depth" (Eph. 3:18). This refers to the Lord's cross. The breadth is the cross-beam, on which the hands were stretched out; the length is the part from the ground to the crossbeam, to which is fixed the whole body from the hands downwards; the height is the part from the cross-beam up to the top, to which the head is attached; the depth is the hidden part, firmly set in the ground. ${ }^{121}$

The use of the motive of the "root" and the interpretation of the "breadth and length and height and depth" as the cross in the context of the hermeneutical theory, probably, can imply a remote reference to the connection of these motives in the Gospel of Truth, because in this Nag Hammadi treatise it is stated that "all the emanations of the Father are pleromas and the root of all his emanations is in the one who made them all grow up in himsef,"122 namely that "the place to which they send their thought, that place is their root, is what takes

(121) Augustine, De Doctrina Christiana, ed. and tr. GREEN, pp. 127-129.

(122) Tr. of AtTRIDGE and MACRAE, in: The Nag Hammadi Library, p. 60. 
them up in all the heights to the Father." ${ }^{123}$ It is stated about Jesus that "in schools he appeared (and) he spoke the word as a teacher"124 and that he took the book "which no one was able to take, since it remains for the one who will take it to be slain." 125 And, finally, "He put on that book, he was nailed to a tree, he published the edict of the Father on the cross." 126

It happens then that the figure of Crucified Christ is as if intewoven into the texture of the letters of Scripture. Similar conception of an anthropomorphic Divine figure interwoven in the text of the Scripture existed in the medieval Jewish mystical tradition and was based on an assumption that the text of the Torah consists of the Divine names, while the "measures of stature" (shi'ur qomah) of the gigantic Divine Body also had their names which were inserted into the texture of the holy scriptural text. As E. Wolfson has remarked, the verses of the Torah were transformed into a Divine anthropomorphic form, and this idea was clearly formulated by the Thirteenth-century kabbalisits, who interpreted the words of the Torah as the symbols of the fullness of God, one of the expressions of which was the conception of the "macroanthropos."127

In a Christian medieval context similar idea is expressed by a German mystical writer of the Fourteenth century Henry Suso who wrote in the 3 chapter of his Little Book of Eternal Wisdom: "thou shouldst seek all thy rest in Me, shouldst willingly suffer wrong from others, desire contempt, mortify thy passions, and die to all thy lusts. Such is the first lesson in the school of wisdom, which is to be read in the open, distended book of My crucified body."128

In the comprehension of Augustine, the Divine Body is co-extended with the cross, and this shape, probably, indicates on the reference to an ancient Christian teaching of a non-anthropomorphic tradition of the treatment of the Divine Form and on the implantation of the Divine Name into the text/texture of the Bible. This

(123) Tr. of ATtRIDGE and MACRAE, in: The Nag Hammadi Library, p. 60.

(124) Ibid., p. 41.

(125) Ibid.

(126) Ibid., p. 42.

(127) E. R. WOLFSON, "The Mystical Significance of the Torah Study in German Pietism," The Jewish Quarterly Review, 84 (1993), p. 48.

(128) H. SusO, Little Book of Eternal Wisdom, London, 1910, p. 34. 
supposition can be supported by adducing again some early Christian material.

A. G. Gottstein has suggested that "as first-born Jesus restores the original zelem. The concept of image of God allows Paul to address Gentiles as well as Jews, for this image is not a natural body, but a body of the elect, that is, the church." 129 In apocryphal Acts of John 98 (13) the church as the body of the elect is presented as the luminous cross.

And when he (Jesus) had said this he showed me a Cross of Light

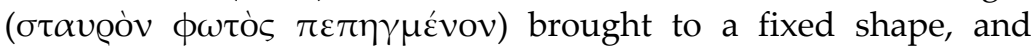
around the Cross a great crowd, which had no single form; and in it (the Cross) was one form and the same likeness. And I saw the Lord himself above the Cross, having no shape but only a kind of

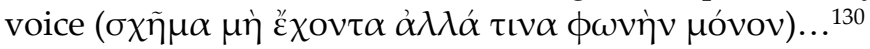

The last phrase echoes a reference to Deut. 4:11-12 "And ye came near and stood under the mountain; and the mountain burned with fire unto the midst of heaven, with darkness, clouds, and thick darkness. And the Lord spake unto you out of the midst of the fire: ye heard the voice of the words, but saw no similitude; only ye heard a

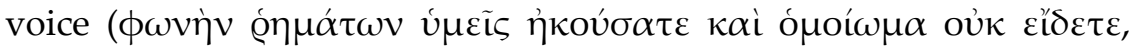
$\dot{\alpha} \lambda \lambda^{\prime} \eta \eta$ nomists' replacement of the concept of the human form of Yahweh by the concept of the Divine Name, discussed by M. Barker. ${ }^{131}$ On the other hand, it is paraphrased in the account of the fall of the First Man in the Naassene mythology related by Hippolytus (Ref. 5.6.4).

This, he says, the Thracians who dwell around Haemus, and the Phrygians similarly with the Thracians, denominate Corybas, because, (though) deriving the beginning of his descent from the head above and from the unportrayed brain, and (though) permeating all the principles of the existing state of things, (yet) we do not perceive how and in what manner he comes down. This, says

(129) A. G. GotTSTEIN, "The Body as Image of God in Rabbinic Literature," HTR, 87 (1994), p. 194.

(130) New Testament Apocrypha, ed. W. SCHNEEMELCHER and R. WILSON, vol. 2, Westminster, 2003, p. 185.

(131) M. BARKER, “Temple Imagery in Philo: an Indication of the Origin of the Logos?" in: Templum Amicitiae: Essays on the Second Temple Presented to Ernst Bammel, ed. W. HorburY, Sheffild, 1991, pp. 83-84. 
he, is what is spoken: "We have heard his voice, no doubt, but we have not seen his shape."132

This myth was adduced by scholars within the framework of the interpretation of the Anthropos-myth employed by the author of apocryphal Acts of Peter, ${ }^{133}$ narrating about the reverse crucifixion of the Apostle. Before his martyrdom, Peter begins his final preaching with the words: "O name of the cross, mystery that is hidden, $\mathrm{O}$ inexplicable grace that is unspoken in the name of the cross!"134 An expression "name of the cross," represents, probably, a version of the expression

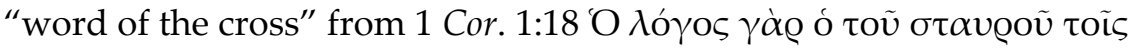

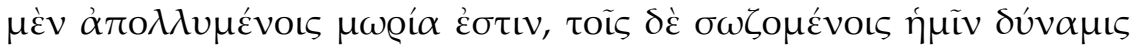
$\theta \varepsilon$ ov $\dot{\varepsilon} \sigma \tau \mathrm{\tau}$. (For the preaching of the cross is to them that perish foolishness; but unto us which are saved it is the power), if to take into consideration again the noticed by G. Quispel interchangeability of the notions of the Name and the Logos: "The Didache $(10,2)$ speaks about the "Name, which thou madest dwell (kateskēnossas) in our heart"... The expression has parallels in Jewish literature. In the Psalms of Solomon it is said: "we will find mercy, when your Name dwells (kataskēnoun) among us" (7:6). This of course is the best imaginable parallel for John 1:14: "the Word became flesh; he came to dwell among us"; it shows how Jewish is the wording of John and how close are the meanings of Logos and Onoma."135

Further, P. J. Lalleman has noted that from the expression in the Acts of John 96.25: "This is the cross which fastened all as Logos..." a reader can deduce "an identification not of Christ and Logos but of cross and Logos." 136 At the end of the final preachiching of Jesus one encounters a puzzling statement:

(101.14-16) "And so I speak, having made rook for the man

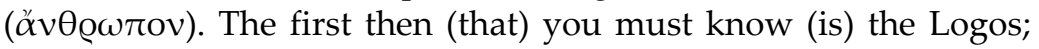

(132) Hippolytus, The Refutation of All Heresies, tr. J. H. MACMAHON, Edinburgh, 1868, p. 141.

(133) J. Z. SMITH, "Birth Upside Down or Right Side Up," History of Religions, 9 (1970), p. 300, n. 61.

(134) New Testament Apocrypha, ed. SCHNEEMELCHER and WILSON, vol. 2, p. 315 .

(135) Quispel, Gnostic Studies, vol. II, p. 228.

(136) P. J. LALLEMAN, The Acts of John: a Two-Stage Initiation into Johannine Gnosticism, Leuven, 1998, p. 183. 
then you shall know the Lord, and thirdly the man (äv $\theta \varrho \omega \pi \mathrm{ov})$, and what he has suffered."137

That all the titles, Man, Lord, Logos, as it seems, refer to the same entity, namely, the cross, can be supported by recalling again the characterization of Philo's Logos summarized by W. Williams: "As is well-known, Philo's Logos is the deity in his accessible aspect; he is the Image of God through which the latter may be seen; he is demiurgic - the instrument (organon) through which the universe was created and ordered. And he is anthropomorphic; God's man (anthropos theou) and 'the Man after His Image'. Significant too is that the name YHWH (Grk. kyrios) seems to be that of the anthropomorphic Logos, the 'second God', while the true, transcendent God is simply To On, 'The Existent.' This suggests that for Philo the Logos is the anthropomorphic god of the Hebrew Bible, Yahweh."138 One may add that as G. Quispel observed, in the Gospel of Truth the Son is characterized by an expression "Proper Name" (kurion onoma), and this expression is a technical term in the Stoic grammatical theory, ${ }^{139}$ thus indicating the way of synthesizing Jewish-Christian and Hellenistic philosophical notions which has lead, probably, to similar synthesizing applied by Augustine to his exegetical theory.

Although the conception of the cross of light was attested in an apocryphal document, in its part suspected of Gnostic influences, it continued to be employed in Christian theology and iconography. The connection between the cross of light in Acts of John and a Greek-

(137) New Testament Apocrypha, ed. W. SCHNEEMELCHER and R. WILSON, vol. 2, p. 186.

(138) Williams, THE SHADOW OF GOD.

(139) "In the first place then Proper Name in relation to God is typically Jewish: šem hammeyuhad. It is found only once in a Greek papyrus: "the Proper Name, which is Ogdoas Theos, who orders and governs everything." But, as Gershom Scholem has pointed out, this text was strongly influenced by esoteric Jewish lore. As far as I know, no other Greek document exists in which it is said that a god has a "Proper Name". This expression is of course Stoic. We may perhaps wonder why the Jews picked up such a technical, grammatical term, in order to express their deepest mystery, but the fact is that they did. The Gospel of Truth is no exception to the rule." (G. QUISPEL, "John and Jewish Christianity," in: IDEM, Gnostic Studies, p. 226). 
writing Syriac author Ps. Macarius (8.3) was observed by P. Lalleman. ${ }^{140}$

To certain persons the sign of the cross (

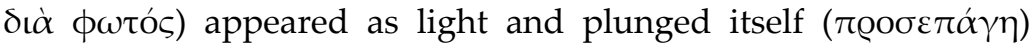
deep into the inner man... To others at times there appeared a splendid robe, such as not found anywhere in the whole world, not made by human hands. Just as when the Lord ascended the mountain with John and Peter, he transformed his garments, making them brilliant like lightning, so too was that robe so that that man, clothed in it, was amazed and struck with awe. ${ }^{141}$

It is interesting to note that this mystical experience in the description of which the terminology clearly correlates with that of the Act of $J o h n$, is connected with the reference to the re-enactment of the event of the Transfiguration of Christ in a personal mystical encounter with the Lord.

One can find a reference to the same conception in another Syriac source, the Sugitha dedicated to the church of H. Sophia in Edessa.

(16) The column that is behind the ambo portrays Golgotha in its form.

And fastened above it is the cross of light, like Our Lord between the thieves. ${ }^{142}$

This image, probably, goes back to the iconographic formula on the vault of the main church of the monastery in Quartmin, ${ }^{143}$ that is, of

(140) P. LALleman, The Acts of John: A Two-Stage Initiation into Johannine Gnosticism, Leiden, 1998, pp. 203-204.

(141) Pseudo-Macarius, The Fifty Spiritual Homilies and the Great Letter, tr. MALONEY, pp. 80-81.

(142) Translation of K. E. MCVEY, "The Domed Church as Microcosm: Literary Roots of an Architectural Symbol," DOP, 37 (1983), p. 95. The translation is of A. Palmer, in: A. PALMER, with L. RodLEY, "The Inauguration Anthem of Hagia Sophia in Edessa: a New Edition and Translation with Historical and Architectural Notes and a Comparison with a Contemporary Constantinopolitan Kontakion," BMGS, 12 (1988), pp. 137-151.

AIN. The column behind (i. e. at the west end of) the platform represents by its special form the rock of Golgotha; and fixed on the top of it, like our Lord between the thieves, is the Cross of Light.

(143) E. J. W. HAWKINS and M. C. MundeL, "The Mosaics of the Monastery of Mar Samuel, Mar Simeon and Mar Gabriel near Kartamin, with a note on the Greek Inscription by C. Mango," DOP, 27 (1973), pp. 279-296; 
the cross with its four arms and four rays issuing from behind it. The luminous cross explicitly acquires the shape of the Name of God on the vault of the Baptistery in Albenga (late 5th c.), ${ }^{144}$ where the monogram of Christ is in an innermost circle, and both the circle and the monogram, together with $A$ and $\Omega$, are repeated in two radiating outer circles, with a gradual decrease in the intensity of colour. This cross-name has six rays, while in the scene of the Transfiguration of Christ in the apse of the monastery of St. Catherine on Sinai (548$560 / 65)^{145}$ the cloud enveloping Christ is represented as the three radiating transparent spheres into which are inscribed the eight rays. The number of rays in these two iconographic monuments, probably, reflect the number symbolism in the interpretation of the Transfiguration, made by Clement of Alexandria: "while He by His birth,

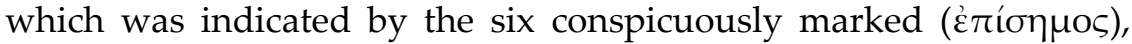
becoming the eighth, might appear to be God in a body of flesh, by displaying His power, being numbered indeed as a man, but being concealed as to who He was."

An implication of the theme of the cross in the iconography of the Transfiguration, probably, reflects an idea of the subordination of a theologia gloriae to a theologia crucis, noted by Fletches-Louis in the synoptic account of the Transfiguration. ${ }^{146}$ This subordination is attested in the iconography of the Transfiguration in St. Apollinare in Classe (ca. 549), ${ }^{147}$ where the cross in the circle is the centre of the whole construction, with the bust of Christ on it. At to the written support of the implication of this theme may be adduced a sermon of Anastasius of Sinai who wrote that in the moment of the Transfigura-

A. PALMER, Monk and Mason on the Tigris Frontier: the Early History of Tur Abdin, Cambridge, 1990, pp. 113-148.

(144) J. WILPERT, W. N. SCHUMACHER, Die Römischen Mosaiken der kirchlichen Bauten vom IV-XIII Jahrhundert, Freiburg-in-Breisgau, 1976, Pl. 86; B. BRENK, Spätantike und frühes Christentum, Frankfurt am Main, 1977, Pl. 20.

(145) G. H. FORSYTH, K. WeITZMANN, The monastery of Saint Cathrine at Mount Sinai, The Church and Fortress of Justinian, 2 vols., Ann Arbor, Mich., 1965-1971, Pl. CIII-CXXVII; CXXXVI-CLXXXVII.

(146) FLETCHER-LOUIS, "The Revelation of the Sacral Son of Man," pp. 286-288.

(147) F. W. DeichmanN, Ravenna, Hauptstadt des spätantiken Abendlandes, vol. 1, Geschichte und Monumente, vol. 2, Kommentar, Wiesbaden, 1969-1976; vol. 1, p. 261ff. and 339; vol. 2, Tl. 2, p. 245ff. E. DinKLER, Das Apsismosaik von S. Apollinare in Classe, Cologne and Opladen, 1964. 
tion Christ was "...as in the Golgotha in the midst of two living creatures in a manner befitting cross, so in the midst of Moses and Ilia in

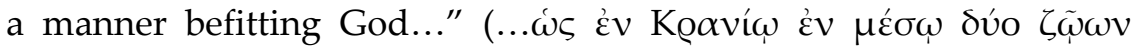

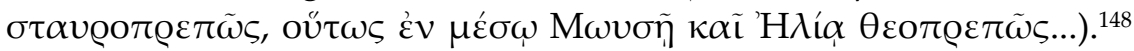
In this way Anastasius indicated on the connection of the Crucifixion and the Transfiguration, which can support the suggestion that the eight rays in the Sinai mosaic can be derived from the Quartmin formula of the cross with four rays, considering the similar motive of the three radiating spheres in both monuments.

\section{EXCURSUS}

The liberal arts, which served as an important instrument for the interpretation of the Scripture in the hermeneutical theory of Augustine, as it can be demonstrated, were integrated into an ancient conception of heavenly ascent of the soul in various cultural and religious contexts.

A connection of the liberal art with the realm of the soul was a well-established idea in the Neo-Platonic tradition. As it has been demonstrated by P. Merlan, ${ }^{149}$ Iamblichus argued sometimes pro, sometimes contra the identification of the soul with the three branches of mathematics (i. e. arithmetic, geometry, and harmonics) while Proclus finally identified the soul with the four branches (with astronomy included). "All these identifications of the soul and the mathematics may ultimately be a correct or a mistaken interpretation of the Timaeus." 150

On the other hand, in Philo's allegorical exegesis (De vita Mosis, Lib. II, 11, 114-115), the gold plate in the form of a crown on the head of the High Priest entering the Holy of Holies is also connected with arithmetics, geometry, and music.

A piece of gold plate, too, was wrought into the form of a crown with four incisions, showing a name which only those whose ears and tongues are purified may hear or speak in the holy place, and no other person, nor in other place at all. That name has four letters, so says that master learned in divine verities, who, it may be,

(148) A. Guillou, "Le Monastère de la Theotokos au Sinai," Mélanges de l'école française de Rome, 67 (1955), p. 239, 19-20.

(149) P. MERLAN, From Platonism to Neoplatonism, The Hague, 1960, pp. 11-33.

(150) Ibid., p. 25 
gives them as symbols of the first numbers, one, two three and four; since the geometrical categories under which all things fall, point, line, superficies, solid, are all embraced in four. So, too, with the best harmonies in music, the fourth, fifth, octave and double octave intervals, where the ratios are respectively four to three, three to two, two to one and four to one. ${ }^{151}$

In an adduced earlier remark of G. Scholem the theme of the Name of God on a golden plate of the High Priest is elaborated in a Jewish Merkabah literature in the theurgic context, as this scholar formulated it: "Several aggadic sayings state that the angels bear the name of God imprinted on their hearts, and this may explain the custom of the Merkabah mystics to add the Tetragrammaton or one of its many substitutes to the names of the angels. In the Midrash Tehillim, R. Levi says: 'A tablet with the name of the Holy One, blessed be He, is engraved on the hearts of the angels as a sort of mark [asteriscus]'."152

This text almost literally corresponds to the discussed here in detail Clement's description of the "Name engraved ( $\left.\bar{c}^{\prime} \gamma \varepsilon \chi \alpha \varrho \alpha \gamma \mu \varepsilon \dot{v} \nu \mathrm{v}\right)$ in the heart," and both texts have similar features with the Chaldaean theurgic elevation. According to H. Levy, "two passages of Proclus complementary to each other deal with a second group of magical signs. According to this author, the Chaldaeans believed that the 'sign' ( $\chi \alpha \varrho \alpha \kappa \tau \eta \emptyset)$ ) set in the heart' of the human soul consisted of a combination of semicircles and of the character $X$, and that 'the gods themselves' had communicated the psychic signs of several Greek heros and of Plato, as well as their 'mystic names' which bring about their apparition. The last piece of information bears on Chaldaean theurgy only to the extent in which it concerns Plato. For Psellus relates that Julian the Chaldaean 'beheld' Plato's soul and 'questioned it at will'. We have no knowledge of his method of interrogation, but the Chaldaean psychological doctrine permits us to form some idea of the manner in which Plato's soul was supposed to appear. While the apparition of Hecate was represented as that of a speaking flame, the philosophers's soul became visible as a geometrical luminous figure. The belief that the apparition of the soul consists of semi-

(151) Tr. F. H. COLSON, cf. Philo, Cambridge, MA, 1958, pp. 503-505; Plilonis Alexandrini opera quae supersunt, vol. IV, ed. L. COHN, P. VENDLAND, Berlin, 1902, p. 227.

(152) SCHOLEM, Jewish Gnosticism, p. 71. 
circles and of the character $X$ derived from Plato's Timaeus, upon which Chaldaean metaphysics are based."153

On the other hand, a detailed elaboration by Clement of Alexandria of the theory of the Name of God, contained in the Stromata VI, cap. XVI. 140, 2-4, devoted to the interpretation of the Transfiguration of Christ, seems to be a Christian version of the theory of "voces mysticae," to a certain extent comparable to the Chaldaean symbolswords. Moreover, a mystical ascent with the help of the "voces mysti$c a e^{\prime \prime}$ is contained in a textbook on Trivium and Quadrivium, familiar to all the literate people of the early Latin Middle Ages, De nuptiis Philologiae et Mercurii, II, 202-207, of Martianus Capella, where he, according to H. Lewy, "describes the deification (cf. ibid., 207 'apopheosin') of Philologia, guided by Athanasia, the daughter of Apotheosis (cf. ibid., I, 140), after the pattern of the Chaldaean mystery of immortalisation." 154

(Book II, 202-204) On her knees beside the wall of the outer periphery, concentrating the whole attention of her mind, she prayed long in silence, and according to ancient ritual, uttered certain words with her inner voice, words varying in number according to the practice of different peoples, words of unknown sound, made up of alternating combinations of letters. In these words she paid reverence to the presiding deities of the world of pure understanding, and to their ministers, to whom the powers of the sensible world owe veneration, and to the entire universe contained by the depth of the infinite Father; then she invoked those certain three gods and the others who shine on the seventh day and night. She prayed also, according to the mysteries of Plato, to those powers Once and Twice hapax kai dis epekeina, to the Maiden of the Source. ${ }^{155}$

Almost all the deities to which Philologia prayed were identified by $\mathrm{H}$. Lewy as Chaldaean, and those of them which were not directly mentioned by this scholar can be easily identified as the Chaldaean gods or divine powers, described and analysed in his book. Thus, the

(153) H. LEWY, Chaldaean Oracles and Theurgy, Le Caire, 1956, pp. 252254.

(154) Ibid., p. 177, n. 3.

(155) Tr. by W. H. StAHL and R. JOHNSON with E. L. Burge, in: Martianus Capella and the Seven Liberal Arts, vol. II, The Marriage of Philology and Mercury, New York, 1977, p. 61. 
term "Depth" is applied... to the Pleroma of the intelligible world, called "paternal," because the Supreme God is Himself the noetic All." 156 The "certain three gods," according to H. Lewy, are the "three entities, who are called in the Chaldaean Oracles by various names:

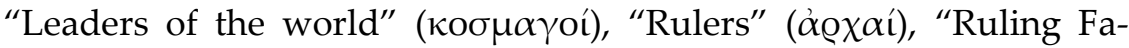

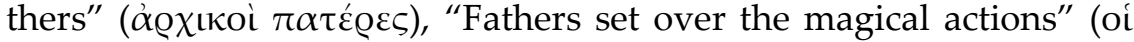

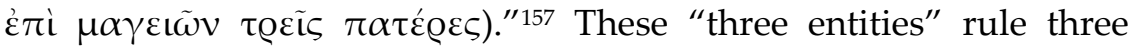
world-circles, namely, "the Empyrean, viz. the Intelligible World, forming the outermost circle; the Ethereal World, comprising the zone of the fixed stars, as well as that of the planets; the so-called Hylic World, viz. the sublunar region including the earth. ${ }^{158}$ The gods called by Martianus Capella as "the others who shine on the seventh day and night" can be identified, probably, with the Chaldaean planetary gods, because their appearance seems to be connected with the time ("who shine on the seventh day and night"), and H. Lewy identified an expression of the Oracle "in the times," that is, when they were begotten as the "sons" by the Supreme God, as "a mere poetical periphrase, which indicates the temporal creation of this class of gods." 159

The "powers hapax kai dis epekeina" of Martianus Capella are the Chaldaean two Intellects, namely, the demiurgical Intellect which "is known as the 'doubly transcendent', in contradistinction from the First Intellect designated as the 'singly transcendent'."160 The demiurgical Intellect "is signified by the dyad, which, together with the Paternal Monad, constitutes the Source, wherefrom the 'bond' of the 'measurable Triad' (i. e. the world-shaping Ideas) 'flows forth'."161 This arithmetical consctruction seems to be reproduced in a modified way by Martianus Capella in Book VII: "The number three also represents the perfection of the universe: the monad refers to the Divine Creator; the dyad to the generating matter; and the triad to ideal forms." 162

(156) LewY, Chaldaean Oracles, p. 160. Indication on Martianus Capella, p. 159 , n. 351.

(157) Ibid., pp. 138-139. Indication on Martianus Capella, p. 139, n. 274.

(158) Ibid., p. 137.

(159) Ibid., p. 159.

(160) Ibid., p. 115. Indication on Martianus Capella, p. 77, n. 43.

(161) LeWY, Chaldaean Oracles, p. 115.

(162) Tr. by StAhL, JoHnson, Burge, in: Martianus Capella, vol. II, p. 278. 
And, finally, the "Maiden of the Source" is the Chaldaean Hecate, a single deity with four manifestations. ${ }^{163}$ The nature and character of this goddess, described by H. Lewy, can be applied to the personifications of the four sciences of the Quadrivium, who are represented by Martianus Capella as real goddeses. According to H. Lewy, "Zoe, Psyche, Physis (also called: Ananke) and Heimarmene are four manifestations of the Chaldaean Hecate. The first produces the pure life of the blessed immortals, the second ensouls the worlds, the third rules by the law of necessity over the spheres, the fourth, mistress of the demons, dominates the terrestrial zone. The reason for the diversity of the qualitites attributed to this goddess is to be sought in the Chaldaean system of the universe. The diverse manifestations of Hecate-Psyche, regarded as the power that ensouls all the worlds, correspond to the difference of these worlds. In the region of the stars, known as the "ethereal world," the action of "ensouling" produces regular motion, which in the absence of a centrary force bears the character of pure necessity and is accordingly a manifestation of Nature. Beneath the moon lies the "hylic world," where Spirit is opposed to Matter; there the demonic satellites of the latter are active, dominated by Hecate, who has "ensouled" them. In the noetic region the soul is sublimated and transmuted into the pure principle of Life, by virtue of whose "Strength" she fills even the "highest of all the worlds." 164

The personified Arithmetic, described by Martianus Capella in Book VII, probably, can correspond to the highest aspect of the Hecate, Life (Zoe) who "produces the pure life of the blessed immortals." Arithmetic presents herself to the celestial assembly of gods in the following way: "Heaven knows me, and I am recognized in the mundane realms, which I have produced. I do not consider it beneath my dignity to come to your assembly, though I reckon every one of you as sprouting from my branches. And I ask you in particular, Jupiter, the first of all to spring forth, to acknowledge me as the source of your unique and primordial nature. And the service that I perform for Mercury will not cause you to despise me, the mother of all of you, for I am eager to prove to you the original stock of your mysterious lineage. While I am engaged in such matters on earth, let the host of heavenly bodies recognize the venerable author of their multi-

(163) LEWY, Chaldaean Oracles, p. 94, n. 117.

(164) Ibid., p. 98. 
tude. Before all things, let the monad be called sacred; numbers coming after it and assotiated with it have taught that before everything the monad is the original quickener. For if form is an accident of anything that exists, and if that which numbers is prior to that which is to be numbered, it is fitting to venerate the monad before that which has been called 'the beginning'."165

This doctrine is symbolised by the curious appearance of this science of the Quadrivium. Arithmetic "had a stateliness of bearing that reflected her pristine origin, antedating the birth of the Thunderer himself, and shone in the light of her countenance. Certain strange manifestations on her head gave her an awesome appearance. For from her brow a single, scarecely perceptible, whitish ray appeared, and from it emanated another ray, the projection of a line, as it were, from its original source. Then came a third and a fourth ray, and on to a ninth and a tenth, the first decad - all radiating from her glorious and majestic brow in double and triple combinations. But even as the rays emanated in boundless profusion, so they gradually diminished again in a remarkable way, and she reduced them to one. A robe concealing the operations of universal Nature covered her manifold and intricate undergarment." 166 "Then the ray that first protruded from her forehead, jutting straight outward, bathed the head of Jove in its luster. At this strange apparition of countless rays suddenly proliferating, some of the earthly and sylvan deities, fancying that Arithmetic was sprouting heads like the Hydra, glanced at Hercules." 167 This description of the Arithmetic can correspond to the Chaldaean doctrine, namely, that "the proportion of Reason to Matter is not the same in all the regions of the Universe; it depends on the distance of a given zone from the celestial place of origin. The noetic world is immaterial; it is pure Intellect. In the celestial vault (viz. the sphere of the fixed stars), which adjoins the noetic Empyrean, the ideal element predominates, but there is an admixture of 'something corporeal'. Because of this, the ray of the Ideas is said to be 'dimmed', when penetrating into the world of the spheres. The material element is preponderant in the sublunar region, which is therefore called in the Oracles 'dark-glowing' or 'light-hating'; the 'Thunderbolts' of the

(165) Tr. by Staht, JOHnSON, Burge, in: Martianus Capella, vol. II, p. 276.

(166) Ibid., pp. 274-275.

(167) Ibid., p. 275. 
Ideas are said to 'break themselves' on its resistance."168 This correspondence seems to support the identification of Arithmetic as one of the manifestations of the Chaldaean Hecate.

In the Book IX, 322-323 of The Marriage of Philology and Mecury the Harmony declares that she has a celestial origin and deals with both the intelligible numbers which govern the order of the heavens and with the earthly numerical ratios which rule the order of the material universe. "From the time that the limitless universe of the ineffable Creator begot me as the twin sister of heaven, I have not forsaken numbers; I followed the courses of the sidereal spheres and the whirling motion of the entire mass, assigning tones to the swiftly moving celestial bodies. But when the Monad and first hypostasis of intellectual light was conveying to earthly habitations souls that emanated from their original source, I was ordered to descend with them to be their governess. It was I who designated the numerical ratios of perceptible motions and the impulses of perfect will, introducing restraint and harmony into all things, a subjet which Theophrastus elaborated upon as a universal law for all mankind."169 In this way Harmony seems to have an intermediate position in between the intelligible universe, where all the three have common principle and the incoporated order and ratios which rule the material universe, and can be identified with the second aspect of the Chaldaean Hecate, Soul (Psyche) who, in the interpretation of H. Lewy, "ensouls the worlds" in the region of the stars and this "produces regular motion."

Harmony of Martinus Capella mentions "the Monad and first hypostasis of intellectual light," the first of which can be identified with the Chaldaean unique Supreme Being, the Father, ${ }^{170}$ and Martianus says in Book VII (Arithmetic) that "rightly is the monad called Father of All, and Jove - a conclusion corroborated by the causative force of its ideal and intelligible form." 171 The "first hypostasis of intellectual light" of Martianus Capella is, probably, the Aion; an entity which the Oracles call the "Father-begotten Light." 172 His intermediary posi-

(168) LEWY, Chaldaean Oracles, p. 126.

(169) Tr. by STAHL, JoHnSON, BuRGE, in: Martianus Capella, vol. II, pp. 356-357.

(170) LEWY, Chaldaean Oracles, p. 76-78.

(171) Tr. by STAHL, JOHNSON, BuRGE, in: Martianus Capella, vol. II, pp. 276-277.

(172) LEWY, Chaldaean Oracles, p. 99. 
tion is comparable to the intermediary position of the Harmony of Martinus Capella. According to H. Lewy, "Aion is a noetic ('subtle') monad with a dual aspect; on the one hand, he, alone, is sustained by the Vital Force ('Strength') of the Supreme Being, Whose Intellect he, by virtue of his noetic quality, is able to cognize. On the other hand, his function is to transmit the supreme light to the 'Sources and Principles' who are... the general and particular ideas, and to keep these in perpetual circular motion." 173

Finally, the two other personified arts of the Quadrivium, as represented by Martinus Capella, Astronomy, who describes the heaven, (Book VIII) and Geometry, who describes the earth, (Book VI) can be identified with the two lower aspects of the Chaldaean Hecate, the Nature (Physis) who "rules by the law of necessity over the spheres" and Fate (Heimarmene) who "dominates the terrestrial zone."

\section{CONCLUSION}

The conception of the incorporation of the limbs of the Divine Body in the text/texture of the Scripture, elaborated by the Medieval Jewish theoreticians of the Kabbalah, was present as well within the Christian exegetical conceptions, not as an alternative to the Incarnation of the Logos in the Person of Christ, but complementary to it. The roots of this Christian teaching goes back to ancient Jewish-Christian tradition attested in such written documents as the canonical Hebrews Epistle and the extra-canonical Gospel of Truth. Besides the incorporation of the Divine Body in the letters of the Bible, Christian exegetical tradition included also other elements of the Merkabah mystical visionary repertoir, such as the garments of the Logos and the veil of the heavelnly temple, representing the universe with all its earthly history. Finally, as parallel to the Jewish conception of the Torah as the Divine Name there existed a Christian exegetical conception of the Name incorporated in the text of the Scripture in the shape of the cross, representing the luminous transfigured Body of the Logos as the universal church.

\section{SUMMARY}

In this article I made an attempt to demonstrate that the teaching of the embodiment of the Divine Limbs into the text/texture of the Scripture,

(173) LEWY, Chaldaean Oracles, p. 100. 
elaborated by the medieval kabbalisits, and the well-known theory of the incarnation of Christ into the letters of the Bible, which can be found in the writings of such Christian authors as Origen, Augustine, or Maximus the Confessor, stems from the same conception of the spiritual celestial nature of the letters serving as the constructive element for the Divine Name and an instrument of the creation of the world, and this teaching appeared in the Late Hellenistic Jewish and early Christian mystical circles. In the Christian trajectory of the development of this conception an important stage was an interpretation of the events of the Transfiguration and Ascension of Christ made by Clement of Alexandria, in whose view the Transfigured Jesus disclosed to the Christian believers the celestial numerological and alphabetical secrets connected with the mystery of the Divine Name. On the other hand, Clement has interpreted the Transfiguration and Ascension in terms of the ascent of Christ to the Heavenly Temple where he serves as a High Priest uplifting and edifying Christians. This conception correlates with the idea, expressed in the writings of Clement and other Christian authors, that the believers or their virtues constitute the living letters of the celestial alphabet, while Christ completes the heavenly liturgy within the Tabernacle of the Scripture, his Body being incarnated in the written letters (covering of body of the Scripture) while he himself serving as a High Priest, Logos and Teacher, leading his followers to the meanings of the Scripture contained in its soul and spirit. This idea was formulated by Origen as a theory of the Christian spiritually-allegorical exegesis of the Bible, while Augustine has expanded it by producing a synthesis of these Jewish-Christian motives with the elements of Stoic and Neoplatonic philosophical and philological conceptions. In addition, Augustine has made the liberal arts serve as constituent elements for his exegetical theory and practice, and this use of the liberal arts can be explain partly by the fact that in Late Hellenistic culture in various religious contexts they were included as stages and means for reaching the mystical goals of theurgic heavenly ascent. 